Bartın Üniversitesi

Eğitim Fakültesi Dergisi

Cilt 6, Sayı 3, s. 878-901, Ekim 2017

BARTIN - TÜRKIYE

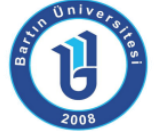

ISSN: 1308-7177
BartinUniversity

Journal of Faculty of Education

Volume 6, Issue3, p. 878-901, 0ctober2017

BARTIN - TURKEY

\title{
Üç Aşamalı Kavramsal Ölçme Aracı İle Öğrencilerin Sindirim Sistemi Konusundaki Kavram Yanılgılarının Tespiti
}

Hüseyin Cihan BOZDAĞ, Öğretmen, Milli Eğitim Bakanlığı, chnbzd@gmail.com, http://orcid.org/0000-0001-6735-7096

Öz: Bu araştırmada yedinci sınıf öğrencilerinin sindirim sistemine yönelik kavram yanılgılarının üç aşamalı test tekniği ile belirlenmesi amaçlanmıştır. Araştırma, İzmir şehir merkezindeki bir devlet ortaokulunun yedinci sınıfında öğrenim gören 230 (119'u kız ve 111'i erkek) öğrenci ile yürütülmüştür. Tarama yönteminin benimsendiği araştırmada, öğrencilerinin sindirim sistemi konusunda sahip oldukları kavram yanılgılarının tespiti için üç aşamalı "Sindirim Sistemi Kavramsal Ölçme Aracı" kullanılmıştır. Betimsel analiz sonuçlarına göre, öğrencilerin sindirim sistemi konusunda düşük kavramsal anlama oranına sahip oldukları belirlenmiştir. Bunun yanı sıra beşi alandan farklı (KY5-8-9-11-12) ("sindirim ürünleri karbonhidrat, protein ve yağdır" ve "yağların sindirimi sadece pankreas özsuyu ile gerçekleşir" gibi), diğerleri alandaki araştırma sonuçlarıyla benzer toplam oniki kavram yanılgısı belirlenmiştir.

Anahtar Kelimeler: kavram yanılgısı, sindirim sistemi, üç aşamalı test, yedinci sınıf

\section{Determining the Misconceptions of Students on Digestive System by Using 3-Tier Conceptual Measuring Tool}

\begin{abstract}
In this study, the purpose is to determine the misconceptions of seventh grade students on digestive system by using a 3-tier testing technique. The study was conducted with 230 (119 femaleand 111 male) students studying at a state school in Izmir city center. The review method was used in the study, and the "3-Tier Digestive System Conceptual Measuring Tool" was used in order to determine the misconceptions of the students on digestive system. According to the results of the descriptive analysis, it was determined that the students had low conceptual understanding rates on digestive system. It was also determined that the students had twelve misconceptions; five of them were different from the field ("digestive products are carbohydrates, protein and fat" and "the digestion of the fats occurs only with the pancreatic juice" etc.), and rest of them were similar with research results in the literature.
\end{abstract}

Key Words: digestive system, misconception, seventh grade, three tier test 


\section{GíRiş}

Fen eğitiminin en önemli hedeflerinden biri öğrencilerin bilimsel kavramları sahip oldukları kavramlar ile ilişki kurarak anlamlı ve kalıcı bir şekilde öğrenmeleridir. Bu doğrultuda edinilen bilgi ve kavramların gündelik hayatla ilişkilendirilmesi ile karşılaşılan problemlerin çözümünde kullanılabilmesinin sağlanması amaçlanmaktadır. Ancak kavram zenginliğine sahip fen bilimleri dersindeki konuların birçoğu soyut kavramlar içermektedir. Dolayısıyla bu durum kavramların anlamlı ve kalıcı bir şekilde öğrenilmesini zorlaştırmaktadır. Son yıllarda yapılan birçok araştırma bulgusu, öğrencilerin ilk kez fen derslerine geldiklerinde öğretime engel teşkil eden bilgiler ile okula geldiklerine işaret etmektedir. Bu sonuçlar öğrencilerin öğretilecek olgu ve kavramlar hakkında bilimsel görüşlerle uyuşmayan kendilerine göre tutarlı, mantıklı ve daha sonra değiştirilmesi nispeten zor bilgi veya inançlara sahip olduklarını göstermektedir (Duit \& Treagust, 2003; Hammer, 1996; Holland, Griffiths \& Woodman, 1997). Bundan dolayı günlük yaşamları, kişisel deneyimleri, inançları, çevresel birikimleri ile gelişmemiş zihinsel becerileriyle kavramları anlamlandırma çabaları gibi etkenler öğrencilerin bilimsel olgu ve kavramlara kendilerine göre mantıklı, tutarlı yanlış anlamlar yüklemesine neden olmaktadır (Ayvacı, Özsevgeç \& Cerrah, 2004; Ercan, Taşdere \& Ercan, 2010; Treagust, 1995). Öğrencilerin bilimsel olmayan bu anlamlandırma faaliyetleri ile ilgili alanyazında; ilkel inançlar (McCloskey, Caramazza \& Green, 1980), ön kavramlar (Hashweh, 1988), ilkel kavramlar (Klopfer, Champagne \& Gunstone, 1983), anlık akıl yürütme (Viennot, 1979), ilkel teoriler (Mintzes, 1984), alternatif yapılar (Pfundt \& Duit, 1991), sağduyu inançları (Halloun \& Hestenes, 1985), alternatif kavram (Driver \& Easley, 1978; Trowbridge \& Mintzes, 1985), çocukların bilimi (Gilbert, Osborne \& Fensham, 1982), kavram yanılgıları (Helm, 1980) şeklinde terimler kullanılmaktadır. Bu terimlerden en çok alternatif kavram ile kavram yanılgısı terimleri kullanılmakta olup bu çalışmada "kavram yanılgısı" tercih edilmiştir.

Kavram yanılgıları; bireyin kültür, dil, gözlemler gibi kişisel deneyim ve etkileşimleri sonucunda oluşmuş, bilimsel olarak kabul gören görüşler ile uyuşmayan ve bilim tarafından gerçekliği kanıtlanmış kavramların öğretilmesini ve öğrenilmesini engelleyici bilgilerdir (Baki, 1999; Çakır \& Yürük, 1999, Wessel, 1999). Bilişsel yapıya tutunarak yeni kavramların oluşmasını engellediği ve kavramlar arasında anlam bütünlüğünü bozduğu için kavram yanılgıları kısa devreye yol açan iletken tellere benzetilebilir (Bahar, 2003; Treagust, 2012). En genel anlamda kavram yanılgıları bireylerin doğal dünyayı ve bilimsel açıklamaları anlamalarını temelden etkileyen, bilimsel görüşlerden farklı olarak bilişsel yapıda güçlü bir şekilde tutunan bilgilerdir. Farkında olmadan yeni bilgi ve becerilerin uygun şekilde edinilmesi veya yapılandırılmasını engellediğinden bilimsel bilgiye ulaşılabilmesi için kavram yanılgılarının üstesinden gelinmesi ya da önlenmesi gerekmektedir (Hammer, 1996; Hasan, Bagayoko \& Kelley, 1999; Treagust \& Chandrasegaran, 2007; Tuncay, Akçam \& Dökme, 2011; Yürük \& Çakır, 2000). Fen bilimleri dersindeki konuların birçoğunun soyut kavramlar içermesi, öğrencilerin öğretim öncesinde ve öğretim sırasında kavram yanılgısına sahip olması ile kavram yanılgılarının değiştirilmesi zor olan doğası nedeniyle anlamlı ve kalıcı öğrenmeye ket vurduğunun gözlenmesi araştırıcıları kavram yanılgılarını belirlemeye, kaynaklarını sorgulamaya, kavram yanılgılarını gidermeyi amaçlayan farklı öğretim tekniklerini kullanmaya ve geliştirmeye itmiş̧ir (Arslan, Cigdemoglu, \& Moseley, 2012; Çakıcı, 2005; Ös, 2006; Özbilen, 2015; Pelitoğlu, 2006; Peşman \& Eryılmaz, 2010; Rule, 2004; Taşlıdere, 2016; Toyoma, 2000).

Fen bilimleri dersini oluşturan konuların birçoğu sarmal ilerleyen, birbirini tamamlayan konulardan oluşmaktadır. Bu konuların ilk yıllardan itibaren sağlam temellere oturtularak öğretimi önemlidir (MEB, 2006). Sarmal olarak ilerleyen konulardan birisi de vücudumuzdaki sistemler ünitesi içinde yer alan sindirim sistemi konusudur. "Sindirim sistemi, besinler ve sindirim" kavramları bireylerin öğretimden önce pek çok önbilgiye sahip olduğu kavramlardır 
(Güngör, 2009). Son yıllardaki birçok araştırma bulgusu öğrencilerin sahip olduğu bu ön bilgilerin öğretim aşamasında sık sık kavram yanılgılarına neden olduğunu göstermektedir. Dolayısıyla öğrencilere aktarılan önbilgiler ile geliştirdikleri kavram yanılgılarının belirlenmesi gerekmektedir. Sindirim sistemine ilişkin yapılan çalışmalar irdelendiğinde çalışmaların; kavram yanılgılarının belirlenmesi (Carvalho ve diğer., 2004; Çakıcı, 2005; Çardak, 2015; Garcia-Barros, Martínez-Losada \& Garrido, 2011; Güçlüer \& Kesercioğlu, 2011; Nunez \& Banet, 1997; Ös, 2006; Öztaş, 2015; Prokop \& Fancovicová, 2006; Teixeira, 2000; Tekkaya, Çapa \& Yılmaz, 2000; Toyoma, 2000; Uğur, 2010), kavram yanılgılarının olası kaynaklarının belirlenmesi (Güngör, 2009; Güngör \& Özgür, 2009; Özgür \& Pelitoğlu, 2008; Pelitoğlu, 2006) ile yöntem ve teknikler (Demir, 2008; Demir, 2012; Ekiz, 2015; Kurtçuoğlu, 2007; Özbilen, 2015; Özsevgeç, Artun \& Ünal, 2012; Rule, 2004; Şahin \& Oktay, 1998; Yel \& Yiğitel, 2005) başlıkları altında ele alındığı görülmektedir.

Alanyazın incelendiğinde, sindirim sistemi konusuna yönelik öğrencilerin birçok kavram yanılgısının bulunduğu görülmektedir. Örneğin, Nunez \& Banet (1997), beslenme ile ilgili 11 ile 14 yaşları arasındaki 444 öğrenci ile yürüttükleri çalışma sonucunda, farklı eğitim kademelerinde olmalarına rağmen bilimsel bilgiden farklı kavramların çoğu kademede baskın olduğu ve düzenli öğretimin bile kavramların etkili bir şekilde yeniden yapılandırmasına yardım edemediğini rapor etmişlerdir. Toyoma (2000) tarafından yaşları 4 ile 8 arasında değişen öğrencilerin sindirim ve solunum ile ilgili biyolojik dönüşümler hakkında farkındalıklarını belirlemek amacıyla mülakata dayalı deney ile yürütülen çalışma sonucunda, öğrencilerin yediklerimize ne olduğu konusunda kavram yanılgıları olduğu belirlenmiştir. Benzer şekilde, Teixeira (2000), öğrencilerin insan sindirim sisteminin yapısı ve görevleri hakkında sahip oldukları kavramlarını araştırmış ve öğrencilerin sindirim sistemini ağız, yemek borusu, karın ve anüs olarak dört yapı ile sınırlandırdıklarını belirlemiş̧tir. Çakıcı (2005), 283 öğrenci ile yürüttüğü çalışmasında öğrencilerin sindirim ile ilgili kavram yanılgılarını belirlemek için açık uçlu sorulardan oluşan anket uygulamış ve anket sonunda 102 öğrenci ile görüşme yapmıştır. Elde edilen sonuçlar, öğrencilerin sindirimin tanımı, sindirimin tamamlandığı organ, asitli içeceklerin sindirime yardım ettiği, anüsün sindirim sistemi organı olduğu ve sindirimin başlayıp bittiği yer gibi konularda birçok kavram yanılgısına sahip olduğunu göstermiştir. Uğur (2010) tarafından yürütülen ve iki aşamalı test tekniğinin benimsendiği başka bir araştırmada ise yutmanın istemli olduğu, çiğneme olmamasının midede sindirimi etkilemediği, su sindirilmediğinden ince bağırsakta değil sadece kalın bağırsakta emildiği, safra kesesi alınmasının yağların sindirimini etkilemediği, karbonhidratların ağızda sindirime uğradığı için midede sindirime uğramadığı gibi çeşitli kavram yanılgıları belirlenmiştir. Şahin ve Oktay (1998), 72 kişilik çalışma grubu ile yürüttükleri çalışma sonucunda öğrencilerin besinlerin mideden kana geçtiği ile ince bağırsaktan emilimin nasıl gerçekleştiği yönünden kavram yanılgılarının bulunduğunu rapor etmişlerdir. Benzer şekilde, Güngör (2009) tarafından yürütülen üç yıllık boylamsal bir çalışma neticesinde; iki ucu açık boru şeklinde sindirim kanalı, mideden sonra sindirim sistemi karmaşası, ağızda başlayarak mide veya bağırsakta sonlanan tek ucu açık boru şeklinde sindirim kanalı, sindirimin biricik organı olarak mide, midede besinlerin erimesi veya çözünmesi şeklinde farklı kavram yanılgıları bulunduğu rapor edilmiştir.

Diğer yandan alanyazın irdelendiğinde, kavram yanılgılarını belirlemek ve analiz etmek için mülakatlar (Osborne \& Gilbert, 1980; Thompson, \& Logue, 2006), çoktan seçmeli testler (Schmidt, 1997), kavram haritaları (Novak \& Gobin,1984), sözcük ilişkilendirme testleri (Sutton, 1980) veya bu yöntemlerin kombinasyonları kullanılmaktadır. Çoktan seçmeli testler hızlı, kolay ve büyük gruplara uygulanabilmesi ile verilere daha çabuk ulaşılabilmesi nedeniyle son yıllarda daha çok tercih edilmektedir. Ancak çoktan seçmeli testler gerçekten bilimsel bilgi neticesinde doğru yanıtı seçen birey ile şans eseri doğru yanıtı seçen bireyleri ayıramamaktadır. Çoktan seçmeli testlerin bu dezavantajı nedeniyle Treagust'ın (1985) belirlediği kriterler uyarınca iki 
aşamalı testlerin geliştirilmesi hız kazanmıştır. Soru ve gerekçe aşamalarından oluşan iki aşamalı testler öğrencilerin hem doğru cevabı hem de cevaplarına ilişkin doğru gerekçeyi bulmalarını gerektirir. Bu durum çoktan seçmeli testlere göre şans eseri doğru seçeneği tahmin olasılı̆ını azaltmaktadır. Ancak iki aşamalı testlerin de kendilerine özgü dezavantajları vardır. Araştırmacılar öğrencilerin her iki aşamaya da yanlış cevap vermiş olmasının nedeninin kavram yanılgısından mı yoksa öğrencinin bilgi eksikliğinden mi kaynaklandığını belirleme de iki aşamalı testlerin yetersiz kaldığını belirtmişlerdir (Hasan, Bagayoko \& Kelley, 1999). Bunun üzerine yapılan çalışmalar iki aşamalı testlere bireylerin verdikleri cevaplardan ne seviyede emin olduğunun belirlendiği kendine güven aşamasının eklenmesi ile oluşturulacak üç aşamalı testler ile bahsedilen eksikliğin giderilebileceğini göstermiştir (Caleon \& Subramaniam, 2010). Bu doğrultuda son yıllarda fen eğitiminde kavram yanılgılarının teşhisi için birçok araştırmacı üç aşamalı testleri tercih etmektedir (Aykutlu \& Şen, 2012; Caleon \& Subramaniam, 2010; CetinDindar \& Geban, 2011; Çetinkaya \& Taş, 2016; Peşman \& Eryılmaz, 2010;). Sindirim sisteminde ise kavram yanılgılarını teşhis etmeye dönük olarak test, mülakat, anket, görüşme formu ve açık uçlu soru tekniklerinin daha çok tercih edildiği, iki ve üçaşamalı test tekniklerinin kullanıldığı araştırma sonuçlarının ise sınırlı sayıda bulunduğu gözlenmiştir (Çakıcı, 2005; Güçlüer \& Kesercioğlu, 2011; Ös, 2006; Toyoma, 2000; Uğur, 2010). Bu bağlamda yürütülen çalışmanın amacı, üç aşamalı test tekniğinin kullanılarak yedinci sınıf öğrencilerinin sindirim sistemi konusu ile ilgili kavram yanılgılarının belirlenmesidir.

\section{YÖNTEM}

\subsection{Araştırmanın Modeli}

$\mathrm{Bu}$ araştırmada, 7. sınıf öğrencilerinin sindirim sistemi konusunda sahip oldukları kavram yanılgılarının belirlenmesi amaçlandığından tarama yöntemi kullanılmıştır. Tarama yöntemi, geçmişte ya da halen var olan bir durumun olduğu şekliyle betimlenmesini amaçlayan bir yaklaşımıdır (Karasar, 2009).

\section{2. Çalışma Grubu}

Araştırma, 2016-2017 eğitim- öğretim yılında İzmir ili Buca İlçesinde bulunan bir devlet ortaokulun yedinci sınıfında öğrenim görmekte olan $111^{\prime}$ i erkek (\%48) ve 119'u kız (\%52) olmak üzere toplam 230 öğrenci ile yürütülmüştür.

\subsection{Veri Toplama Aracı}

Yedinci sınıf öğrencilerinin sindirim sistemi konusundaki kavram yanılgılarını teşhis etmek amacıyla fen bilimleri dersi öğretim programında (MEB, 2013) belirtilen kazanımlar doğrultusunda üç aşamalı "Sindirim Sistemi Kavramsal Ölçme Aracı (SSKÖA)" hazırlanmıştır. Ölçme aracının hazırlanışında alanyazındaki çalışmalar, ders kitapları, ders öğretmenleri ile yapılan görüşmeler, öğrencilerin sınıftaki görüşleri ile yazılı sınavlarda verdikleri yanıtlar da dikkate alınmıştır. Toplam on iki sorudan oluşan testin iki soru maddesine $(S 1, S 7)$ ait seçenekler Uğur (2010) tarafından hazırlanan iki aşamalı testten, bir sorunun (S10) soru kökünde yer alan içerik ise Türk Eczacılar Birliği (TEB, 2006) dergisinden edinilmiştir.

SSKÖA gündelik hayatla ilişkili şekilde hikâye formunda hazırlanmıştır. Dolayısıyla öğrencilerin okuduğunu anlama ve düşünerek cevap vermesi amaçlanmıştır. Testte her bir soru 3 aşamadan oluşmaktadır. Illk aşama, olası kavram yanılgılarını içeren çeldiricilerle birlikte doğru yanıtın yer aldığı çoktan seçmeli 4 seçenekten oluşan soru kısmıdır. ikinci aşama, ilk aşamada verilen cevaplara ilişkin gerekçelerin yer aldığı çoktan seçmeli kısımdır. İkinci aşamada öğrencilerin istedikleri gerekçeleri yazabilecekleri açık uçlu bir seçenekte bulunmaktadır. Birinci aşamaya verilen cevabın muhtemel gerekçesi ikinci aşamada kendi şıkkında bırakılmıştır. Örneğin birinci aşamadaki " $A$ " şıkkı için ikinci aşamada muhtemel gerekçe yine " $A$ " şıkkında 
belirtilmiştir. Üçüncü aşama ise birinci ve ikinci aşamada verilen yanıtlardan ne derece emin olunduğunun sorulduğu kendine güven aşamasıdır. Kendine güven aşamasında "Emin Değilim $(E D)$ ", "Kararsızım (K)", "Eminim (E)" ve "Oldukça Eminim (OE)" olmak üzere dört seçenek yer almaktadır. Ölçme aracının öğretim programında belirtilen kazanımlara uygunluğu, kavram yanılgılarını ortaya çıkarmada yeterliği, öğrenci düzeyi ile okunabilirlik ve anlaşılabilirlik boyutlarındaki uygunluğu için biri Biyoloji Öğretimi alanında Yardımcı Doçent, biri Fen Öğretimi alanında Araştırma Görevlisi, biri doktora eğitimi almış Fen Öğretimi alanı uzmanı, ikisi Fen Bilimleri Öğretmeni olmak üzere beş alan uzmanın görüşü alınmıştır. Yapılan değerlendirmeler neticesinde soru cümlelerinin yazım, cümle ve içerik yönünden net algılanabilmesine yönelik bir takım düzeltmeler gerçekleştirilmiştir. Örneğin; üçüncü soruda suyun emilimine yönelik "suyun büyük bölümünün" ifadesi, altıncı soruda "besinlerin sindirimi sonucunda" ifadesi, onikinci soruda yağ içeren besinler ile ilgili kısıma "fındık" ifadesi eklenmiş, onbirinci soru için belirlenen kazanımların birinde ise düzeltmeye gidilmiştir. Kapsam geçerliği sağlanarak son şekli verilen SSKÖA pilot uygulama için 26 yedinci sınıf öğrencisine uygulanmıştır. Uygulama süresi 40 dakika olarak öngörülse de cevaplama süresinin ortalama 20-25 dakika olduğu gözlenmiştir. Uygulamadan elde edilen veriler Microsoft Office Excel ve SPSS 22.0 programında değerlendirilmiş ve güvenirlik katsayısı (cronbach alpha $=\alpha$ ) testin ilk aşaması için 0,64, iki aşama için 0,71 ve testin tamamı yani üç aşama için 0.76 olarak belirlenmiştir. Pilot uygulamadan alınan sonuçlar SSKÖA'nın ölçüm güvenirliğine sahip olduğuna işaret ettiğinden asıl uygulamaya geçilmiştir.

\subsection{Verilerin Toplanması ve Analizi}

Öğrenci cevapları betimsel istatistik teknikleri ile değerlendirilmiştir. Veri setinin analizinde Microsoft Office Excel ve SPSS 22.0 programları kullanılmıştır. Uygulama için Aslan, Çiğdemoğlu \& Moseley (2012) tarafından belirtilen kriterler ile Pesman \& Eryilmaz (2010) tarafından öngörülen puanlama anahtarı uyarınca Tablo 1'deki kategoriler oluşturulmuştur.

Tablo 1

Puanlama Kategorileri

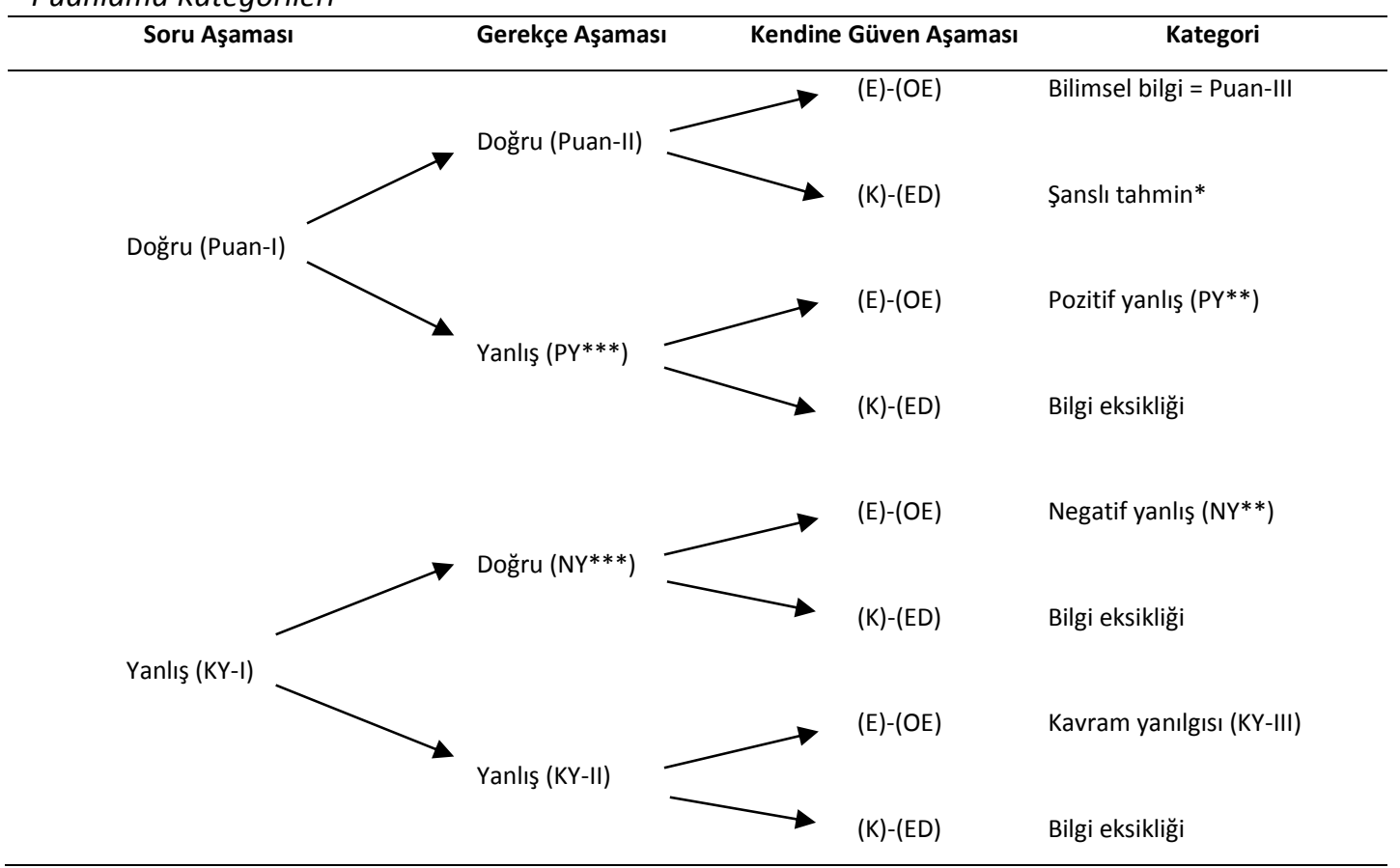

( $\mathrm{E}=$ Eminim, OE= Oldukça Eminim, ED=Emin Değilim, K=Kararsızım)

(*) Aynı zamanda alanyazında kendine güven eksikliği ya da bilgi eksikliği olarak belirtilmektedir.

(**) Üçüncü aşamanın dahil edilmesiyle veri analizinde kullanılan kategoridir.

$(* * *)$ iki aşamalı testlerde değerlendirilen ancak bu çalışmada kulanıımayan kategoridir. 
Oluşturulan kategoriler ile puanlamaya ilişkin kodlama bilgileri şu şekildedir;

IIk Aşama Puanı (Puan-I): Öğrencilerin sadece ilk aşama için verdikleri cevap dikkate alınmıştır. Doğru cevaplar "1", diğerleri "O" olarak kodlanmıştır.

iki Aşama Puanı (Puan-II): Testin ilk iki aşaması ele alınarak hesaplanmıştır. Öğrencilerin hem ilk aşama hem de ikinci aşama için verdikleri cevaplar doğru ise "1", diğerleri "O" olarak kodlanmıştır.

Üç Aşama Puanı (Puan-III): Testin üç aşaması da birlikte ele alınarak hesaplanmıştır. Öğrencilerin hem ilk aşama hem de ikinci aşama için verdikleri cevaplar doğru ve üçüncü aşamada verdikleri cevap " $E$ " ya da "OE" şeklinde ise "1", diğerleri "O" olarak kodlanmıştır.

Toplam Kendine Güven (TKG): Öğrencilerin sadece üçüncü aşamada verdikleri yanıtlara göre hesaplama yapılmıştır. Bu aşamada verilen yanıt " $E$ " ya da "OE" şeklinde ise " 1 ", "ED" ya da " $K$ " şeklinde ise " 0 " olarak kodlanmıștır.

ilk Aşama Kavram Yanılgısı (KY-I): Testin ilk aşamasına verilen cevaplar dikkate alınmıştır. Öğrenciler ilk aşamadaki soruda olası kavram yanılgılarını içeren çeldiriciyi seçtiklerinde "1", aksi halde "O" olarak kodlanmıştır.

iki Aşama Kavram Yanılgısı (KY-II): Testin ilk iki aşamasına verilen cevaplar dikkate alınmıştır. Öğrencilerin ilk aşamada olası kavram yanılgısını temsil eden çeldiriciyi, ikinci aşamada da ilk aşamadaki çeldiriciye ilişkin gerekçeyi ya da seçtikleri cevaba ilişkin kendi gerekçelerini belirtmeleri halinde "1", diğerleri "0" olarak kodlanmıştır.

Üç Aşama Kavram Yanılgısı (KY-III): Testin üç aşamasına verilen cevaplar birlikte dikkate alınmıştır. Öğrencilerin ilk aşamada olası kavram yanılgısını temsil eden çeldiriciyi, ikinci aşamada ilk aşamadaki çeldiriciye ilişkin gerekçeyi ya da seçtikleri cevaba ilişkin kendi gerekçelerini ve üçüncü aşamada da " $E$ " ya da "OE" şeklinde cevap belirtmeleri halinde " 1 ", diğerleri " 0 " olarak kodlanmıștır.

Şanslı Tahmin (ŞT): Öğrencilerin ilk aşama için doğru cevap, ikinci aşama için doğru gerekçe ile üçüncü aşamada " $E D$ " ya da "K" şeklinde cevapları " 1 ", diğerleri "O" olarak kodlanmıştır.

Pozitif Yanlış (PY): Öğrencilerin ilk aşama için verdikleri doğru cevap, ikinci aşama için verdikleri yanlış gerekçe ve üçüncü aşamada verdikleri cevap " $E$ " ya da "OE" şeklinde ise " 1 ", diğerleri " 0 " olarak kodlanmıştır.

Negatif Yanlış (NY): Öğrencilerin ilk aşama için verdikleri yanlış cevap, ikinci aşama için verdikleri doğru gerekçe ve üçüncü aşamada verdikleri cevap " $E$ " ya da "OE" şeklinde ise " 1 ", diğerleri " 0 " olarak kodlanmıştır.

Pozitif ve negatif yanlış terimleri bilimsel araştırmaların değerlendirilmesindeki hatalar için kullanılan ve kapsam geçerliliğinin sağlanması için analiz edilen öğelerdir. Ayrıca veri analizinde elde edilecek değerlerin çoktan seçmeli testlerin geliştirilmesi aşamasında \%10'dan az olacak şekilde minimize edilmesi gerekmektedir. (Aslan, Çiğdemoğlu \& Moseley, 2012; Halloun \& Hestenes, 1995). Bunun yanında, üçüncü aşamada seçeneklerden emin olunması halinde pozitif yanlış ve negatif yanlış olarak değerlendirme yapılacağı, emin olunmaması halinde ise bilgi eksikliği olarak değerlendirileceği belirtilmiştir (Peşman \& Eryılmaz, 2010).

Bilgi Eksikliği (BE): Testin üç aşaması birlikte değerlendirilmiş olup; öğrencilerin ilk aşama-ikinci aşama-üçüncü aşama için cevap alternatifleri sırasıyla; doğru cevap-yanlış gerekçe-"K" ya da "ED", yanlış cevap-doğru gerekçe--"K" ya da "ED" ve ya yanlış cevap-yanlış gerekçe- "K" ya da "ED" şeklinde ise " 1 ", diğerleri "O" olarak kodlanmıştır. 


\section{BULGULAR VE YORUM}

\subsection{Tanımlayıcı İstatistik}

Üç aşamalı SSKÖA ile yapılan çalışmada \%27'lik alt ve üst gruba dayalı madde analizi verilerine göre, ilk aşama için madde güçlüğü 0,31-0,78, ayırt ediciliği 0,37-0,77, iki aşama için madde güçlüğü $0,28-0,76$, ayırt ediciliği $0,44-0,77$ ve üç aşama için madde güçlüğü $0,21-0,60$, ayırt ediciliği 0,35- 0,77 aralığında belirlenmiştir. Bir test maddesinin güçlük indeksinin 0,20 0,80 aralığında, ayırt edicilik indeksinin ise 0,40 'dan yüksek olması gerektiği, ancak 0,30 'dan büyük maddelerin de kabul edilebileceği belirtilmektedir (Alıcı ve diğer., 2011). Bu bağlamda, SSKÖA'nın ilk aşama, iki aşama ve üç aşama açısından madde güçlük ve ayırt edicilik yönünden uygun olduğu belirlenmiştir. SSKÖA'nın her bir aşamasındaki madde güçlük indeksleri irdelendiğinde ise testin her bir sorusu için ilk aşamadan itibaren giderek azaldığı görülmektedir. Örneğin madde güçlük indeksi ilk aşama, iki aşama ve üç aşama yönünden sırasıyla; soru 1 için 0,$44 ; 0,41$ ve 0,37 , soru 2 için 0,$78 ; 0,76$ ve 0,60 , soru 12 için 0,$56 ; 0,51$ ve 0,42 şeklindedir. Testin üç aşamalı doğasına bağlı olarak gözlenen bu azalışın, öğrencilerin sorulara doğru cevap verme yanında doğru gerekçe bulma ve yaptıklarından emin olma boyutunda eksikliklerinin olduğu ile sorulara belirgin kavram yanılgıları eşliğinde cevap verdiklerine işaret ettiği düşünülmektedir.

Tablo 2

Ölçme Aracının Her Bir Aşaması İçin Tanımlayıcı İstatistik Değerleri

\begin{tabular}{|c|c|c|c|c|c|c|c|c|c|c|c|c|}
\hline SORU & 1 & 2 & 3 & 4 & 5 & 6 & 7 & 8 & 9 & 10 & 11 & 12 \\
\hline Ortalama $(\bar{X})$ & 0,40 & 0,81 & 0,25 & 0,39 & 0,37 & 0,39 & 0,77 & 0,51 & 0,52 & 0,36 & 0,37 & 0,48 \\
\hline SS * & 0,49 & 0,39 & 0,43 & 0,49 & 0,48 & 0,49 & 0,42 & 0,50 & 0,50 & 0,48 & 0,48 & 0,50 \\
\hline \%27 Üst Grup & 46 & 61 & 36 & 42 & 36 & 55 & 58 & 57 & 54 & 39 & 39 & 56 \\
\hline \%27 Alt Grup & 8 & 36 & 2 & 8 & 13 & 7 & 29 & 11 & 9 & 7 & 6 & 13 \\
\hline Güçlük & 0,44 & 0,78 & 0,31 & 0,40 & 0,40 & 0,50 & 0,70 & 0,55 & 0,51 & 0,37 & 0,36 & 0,56 \\
\hline Ayırt Edicilik & 0,61 & 0,40 & 0,55 & 0,55 & 0,37 & 0,77 & 0,47 & 0,74 & 0,73 & 0,52 & 0,53 & 0,69 \\
\hline \multicolumn{13}{|c|}{ Illk aşama için; $\alpha=0,71, \bar{X}=5,63$, *Standart Sapma (SS)= 2,753 olarak bulunmuştur. } \\
\hline Ortalama $(\bar{X})$ & 0,37 & 0,77 & 0,23 & 0,38 & 0,33 & 0,36 & 0,74 & 0,47 & 0,46 & 0,33 & 0,33 & 0,46 \\
\hline SS & 0,48 & 0,42 & 0,42 & 0,49 & 0,47 & 0,48 & 0,44 & 0,50 & 0,50 & 0,47 & 0,47 & 0,50 \\
\hline \%27 Üst Grup & 46 & 61 & 33 & 42 & 34 & 53 & 59 & 57 & 51 & 39 & 36 & 54 \\
\hline$\% 27$ Alt Grup & 5 & 33 & 2 & 7 & 7 & 4 & 27 & 9 & 4 & 5 & 2 & 9 \\
\hline Güçlük & 0,41 & 0,76 & 0,28 & 0,40 & 0,33 & 0,46 & 0,69 & 0,53 & 0,44 & 0,35 & 0,31 & 0,51 \\
\hline Ayırt Edicilik & 0,66 & 0,45 & 0,50 & 0,56 & 0,44 & 0,79 & 0,52 & 0,77 & 0,76 & 0,55 & 0,55 & 0,73 \\
\hline \multicolumn{13}{|c|}{ İki aşama için; $\alpha=0,75, \bar{X}=5,22 \mathrm{SS}=2,927$ olarak bulunmuştur. } \\
\hline Ortalama $(\bar{X})$ & 0,31 & 0,66 & 0,18 & 0,28 & 0,27 & 0,24 & 0,63 & 0,32 & 0,33 & 0,19 & 0,19 & 0,34 \\
\hline SS & 0,47 & 0,47 & 0,38 & 0,45 & 0,45 & 0,43 & 0,48 & 0,47 & 0,47 & 0,39 & 0,39 & 0,48 \\
\hline \%27 Üst Grup & 43 & 54 & 28 & 38 & 33 & 45 & 56 & 47 & 45 & 25 & 26 & 50 \\
\hline$\% 27$ Alt Grup & 3 & 20 & 0 & 3 & 5 & 0 & 19 & 2 & 0 & 3 & 0 & 2 \\
\hline Güçlük & 0,37 & 0,60 & 0,23 & 0,33 & 0,31 & 0,36 & 0,60 & 0,40 & 0,36 & 0,23 & 0,21 & 0,42 \\
\hline Ayırt Edicilik & 0,65 & 0,55 & 0,45 & 0,56 & 0,45 & 0,73 & 0,60 & 0,73 & 0,73 & 0,35 & 0,42 & 0,77 \\
\hline
\end{tabular}

Diğer yandan, ölçme aracının bir kez uygulanması ve testte yer alan maddelerin birbiriyle ne derece tuturalı olduğunun belirlenebilmesi için iç tutarlık güvenirliklerinden cronbach alpha kullanılabilir (Büyüköztürk, 2007). Bir ölçme aracının (testin) güvenilir olarak kabul edilebilmesi için Cronbach alfa katsayısının $(\alpha)$ 0,70'den büyük olması gerekmektedir (Büyüköztürk ve diğer., 2008; Jang, 2003). Maddeler doğru ve yanlış ya da " 1 " ve "0" şeklinde 
iki seçenekli olarak kodlandığında Cronbach alfa katsayısı güvenilirlik hesaplanmasında kullanılabilir. Buna göre ilk aşama, iki aşama ve üç aşaması için $(\alpha)$ güvenilirliğinin sırasıyla 0,71 , 0,75 ve 0,78 olarak belirlenmesi SSKÖA'nın her üç aşamada da güvenilir bir test olduğunu göstermektedir.

Bunun yanı sıra üç aşamalı bir ölçme aracında bulunması gereken bazı varsayımların karşılanması gerekmektedir. Ölçme aracının yapı geçerliliğinin belirlenmesi için iki aşama puanı (Puan-II) ile üçüncü aşamaya ilişkin kendine güven puanları (TKG) arasındaki ilişki Pearson momentler çarpım korelasyon katsayısı ile araştııılmıştır. Buna göre yüksek puan alan öğrencilerin düşük puan alanlara göre kendilerinden daha emin olmaları beklenir (Çataloglu, 2002). Ayrıca, çalışma grubu büyük olduğundan (100'den büyük) pearson momentler çarpım korelasyonunun düşük ya da yüksek olduğuna bakılmaksızın istatistiksel olarak anlamlı bir ilişki bulunması beklenmektedir (Pallant, 2001 akt. Peşman \& Eryılmaz, 2010). Elde edilen verilere göre Puan-II ile TKG arasında pozitif ve anlamlı $(r=.31, p<0,01)$ bir ilişki olduğu, Puan-Il yüksek olanların TKG puanının yüksek olduğu belirlenmiştir. Ayrıca Puan-II ile TKG arasındaki korelasyona ilişkin dağılım (scattegram) grafiğinin yer aldığı Grafik 1 incelendiğinde, bazı öğrencilerin düşük puan almasına rağmen verdiği cevaplarda kendinden emin olduğu görülmektedir. Bu öğrencilerin varlığı korelasyon katsayısı değerini düşürdüğü gibi sindirim sistemi konusunda kavram yanılgılarına sahip olanların yanında şans eseri soruyu doğru cevaplayanların varlığına da işaret etmektedir (Peşman \& Eryılmaz, 2010).

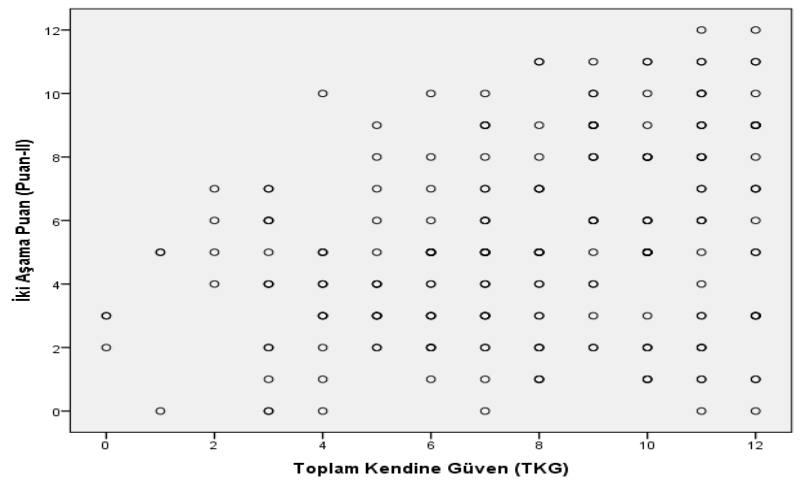

Grafik 1. Puan-II ile TKG korelasyonuna ilişkin dağılım grafiği

Bunun yanında, her bir test maddesine üç aşamada verilen doğru cevaplar ile testten alınan toplam puan arasındaki ilişkiyi belirtmek amacıyla point biserial korelasyon katsayısı hesaplaması yapılmıştır. Point biserial korelasyon katsayısı değerleri "- 1" ile "+1" arasında değişmektedir. Korelasyonda 0,20 'den büyük değerler kabul edilebilir olup; ne kadar yüksek değer elde edilirse test maddesi düşük puan alan öğrenciler ile yüksek puan alan öğrencilerin ayrımını o kadar iyi yapmaktadır (Wuttiprom ve diğer., 2009). Tablo 3'te görüleceği üzere ölçme aracının tüm maddelerine ilişkin korelasyon ortalamasının 0,54 olduğu belirlenmiştir.

Tablo 3:

Puan-III Için Betimsel Istatistik ve Madde Analiz Sonuçları

\begin{tabular}{lcc}
\hline & Güçlük İndeksi & Point Biserial Korelasyon Katsayısı \\
\hline Ortalama & 0,37 & 0,54 \\
Soru sayısı $(0.10-0.19)$ & - & - \\
Soru sayısı $(0.20-0.29)$ & 3 & - \\
Soru sayısı $(0.30-0.39)$ & 5 & - \\
Soru sayısı $(0.40-0.49)$ & 2 & 6 \\
Soru sayısı $(0.50-0.59)$ & - & 2 \\
Soru sayısı $(0.60-0.69)$ & 2 & 4 \\
\hline Soru sayısı $=\mathbf{1 2}, \mathbf{N}=\mathbf{2 3 0}, \overline{\boldsymbol{X}}=\mathbf{3}, \mathbf{9 5}, \mathbf{S S}=\mathbf{2 , 8 9 ,} \boldsymbol{\alpha}=\mathbf{0 , 7 8}$ &
\end{tabular}




\subsection{Sindirim Sistemi Kavramsal Anlama Düzeyi}

Öğrencilerin sindirim sistemi konusunda kavramsal anlama düzeyleri testin ilk aşama, iki aşama ve üç aşamasında verilen doğru cevaplara göre belirlenmiştir. Kendine güven oranı ise ilk iki aşamada verilen yanıtlardan ne kadar emin olunduğuna ilişkin yüzde oranı hesaplanarak belirlenmiştir. Tablo 4 incelendiğinde aşama sayısı arttıkça doğru cevap oranının belirgin şekilde azaldığı gözlenmektedir. Buna göre ilk aşamada \%47 olan ortalama doğru cevap oranının, iki aşamalı \%44 ve üç aşamalı \%33 olduğu belirlenmiştir. İlk aşamada yüksek doğru cevap oranlarının alınmasının asıl nedeni ise çoktan seçmeli bir testte sadece cevabı bulmanın daha kolay olmasıdır (Arslan, Cigdemoglu \& Moseley, 2012).

Kavramsal anlama düzeyine yönelik değerlendirmede öğrencilerin en az \%75'i doğru yanıt seçerse tatmin edici düzeyde kavramsal anlayış olduğu kabul edilmektedir. Oran \%50-74 aralığında ise yeterli, \%25-49 aralığında ise düşük ve \%25'in altında ise oldukça düşük kavramsal anlama düzeyinin bulunduğu değerlendirilir (Gilbert, 1977). Üç aşamalı SSKÖA ile elde edilen sonuçlar ise öğrencilerin \%33'ünün testin tamamına doğru yanıt verdiğini göstermektedir. Dolayısıyla bu sonuç öğrencilerin sindirim sistemi konusunda düşük kavramsal anlama düzeyine sahip oldukları yönünde değerlendirilebilir.

Tablo 4

Sindirim Sistemi Kavramsal Anlama Oranları

\begin{tabular}{ccccc}
\hline Soru & ilk Aşama & $\begin{array}{c}\text { Doğru Cevap Oranı (\%) } \\
\text { iki Aşama }\end{array}$ & Üç Aşama & $\begin{array}{c}\text { \% } \\
\text { Kendine Güven }\end{array}$ \\
\hline 1 & 40 & 37 & 31 & 73 \\
2 & 81 & 77 & 66 & 83 \\
3 & 25 & 23 & 18 & 63 \\
4 & 39 & 38 & 28 & 66 \\
5 & 37 & 33 & 27 & 68 \\
6 & 39 & 36 & 24 & 58 \\
7 & 77 & 74 & 63 & 81 \\
8 & 51 & 47 & 32 & 56 \\
9 & 52 & 46 & 33 & 64 \\
10 & 36 & 33 & 19 & 47 \\
11 & 37 & 33 & 19 & 51 \\
12 & 48 & 46 & 34 & 62 \\
$\bar{X}$ & $\mathbf{4 7}$ & $\mathbf{4 4}$ & $\mathbf{3 3}$ & $\mathbf{6 4}$ \\
\hline
\end{tabular}

Öğrencilerin ilk aşama ile ikinci aşamadaki doğru cevap oranları arasında oldukça düşük bir fark (\%3) vardır. Bu durum ilk aşamada doğru yanıt veren öğrencilerin tamamına yakınının cevaba ilişkin doğru gerekçeye ulaştıklarını göstermektedir. Ancak iki aşamalı ve üç aşamalı olarak değerlendirme yapıldığında öğrencilerin \%11'inin iki aşamada doğru yanıt vermelerine rağmen verdikleri yanıttan emin olmadıkları belirlenmiştir. Dolayısıyla, ilk üç aşamada gözlenen bu farklıııların nedeni kendine güven eksikliği, bilgi eksikliği ya da şanslı tahminden ileri gelmektedir (Arslan, Cigdemoglu \& Moseley, 2012, Peşman \& Eryılmaz, 2010; Taşlıdere, 2016). Ayrıca, öğrencilerin ortalama \%64'ünün verdikleri yanıttan emin olmalarına rağmen sadece \%44'ünün ilk iki aşamada doğru yanıt vermeleri öğrencilerin kavram yanılgısının bulunduğunun bir göstergesidir.

\subsection{Sindirim Sistemi Kavram Yanılgıları}

Sindirim sistemi konusunda öğrencilerin benimsedikleri kavram yanılgılarının teşhisi aşamasında, testin her bir sorusu için olası kavram yanılgılarını içeren çeldiricilerin ayrıntılı bir değerlendirmesi yapılmıştır. Örneğin 1. soru için doğru cevap " $C$ " kabul edilmiş olup; ilk aşamada A, B ve D seçenekleri çeldirici maddelerdir. ikinci aşamada ise, ilk aşamadaki çeldiricilere ait gerekçeler kendi yanıt şıkkında bırakılarak test oluşturulmuştur. Üçüncü 
aşamasının dahil edilmesi durumda; $1.1 \mathrm{~A}-1.2 \mathrm{~A}$ - “ (E)" veya " $(\mathrm{OE})$ ", $1.1 \mathrm{~B}-1.2 \mathrm{~B}$ - "E" veya "OE" ve 1.1 D-1.2 D - "E" veya "OE" alternatiflerinin her biri kavram yanılgılarını temsil etmektedir. Ancak, alanyazında birçok çalışma bulgusu kavram yanılgı oranlarının \%10 ve üzerinde olması halinde anlamlı kabul edilmesi gerektiğine işaret etmektedir (Caleon \& Subramaniam,2010; Tan ve diğer., 2002). Bu doğrultuda, öğrenci cevaplarının kavram yanılgısı boyutunda değerlendirilmesi neticesinde on iki kavram yanılgısı belirlenmiş ve bu kavram yanılgıları Tablo 5'de özetlenmiştir.

Tablo 5

Sindirim Sistemi ile Ilgili Belirlenen Kavram Yanılgıları

\begin{tabular}{|c|c|c|c|c|}
\hline \multicolumn{2}{|r|}{ Kavram Yanılgıları } & \multirow{2}{*}{ Seçenekler } & \multicolumn{2}{|c|}{ Öğrenci } \\
\hline & & & Sayı & (\%) \\
\hline KY1 & Yemek borusunda fiziksel sindirim gerçekleşir. & 1.1a, 1.2a, "E" yada "OE" & 40 & 17 \\
\hline KY2 & Yemek borusunda kimyasal ve fiziksel sindirim gerçekleşir. & $1.1 \mathrm{~d}, 1.2 \mathrm{~d}$, "E" yada "OE" & 26 & 11 \\
\hline KY3 & Suyun büyük bölümü ince bağırsakta emilir. & $3.1 b, 3.2 b$, "E" yada "OE" & 40 & 17 \\
\hline KY4 & Suyun büyük bölümü böbrekte emilir. & 3.1c, 3.2c, "E" yada "OE" & 29 & 13 \\
\hline KY5 & Tüm besin öğeleri hücrelere geçecek kadar küçük değildir. & 4.1a, 4.2a, "E" yada “OE" & 33 & 14 \\
\hline KY6 & Sindirim ağızda başlayıp kalınbağırsakta sona erer. & 4.1d, 4.2d, "E" yada "OE" & 32 & 14 \\
\hline KY7 & En son sindirim ve emilim ince bağırsakta gerçekleşir. & 5.1a, 5.2a, “E” yada "OE" & 47 & 20 \\
\hline KY8 & Sindirim ürünleri karbonhidrat, protein ve yağdır. & $6.1 b, 6.2 b$, "E" yada "OE" & 31 & 13 \\
\hline KY9 & Karbonhidratların yapı taşları yağ asidi ve gliseroldür. & 9.1d, 9.2d, "E" yada “OE" & 29 & 13 \\
\hline KY10 & Midede tüm besinler yapıtaşlarına ayrılır. & 10.1b, 10.2b, “E” yada “OE" & 22 & 10 \\
\hline KY11 & Yağların sindirimi sadece pankreas özsuyu ile gerçekleşir & 11.1a, 11.2a, "E" yada “OE" & 22 & 10 \\
\hline KY12 & Yağların kimyasal sindirimi ağız ve midede gerçekleşir. & $12.1 b, 12.2 b$, "E" yada "OE" & 22 & 10 \\
\hline
\end{tabular}

$\mathrm{KY}=$ Kavram Yanılgısı; E=Eminim; OE=Oldukça Eminim

Veri setinin analizine göre, teşhis edilen kavram yanılgılarının testin her bir aşamasındaki değişimine ilişkin veriler Grafik 2'de belirtilmiş̧ir. Buna göre, test aşama sayısı arttıkça öğrencilerin kavram yanılgı oranlarının belirgin şekilde düştüğü gözlenmektedir. Örneğin, belirlenen kavram yanılgıları için ortalama oranların ilk aşama için \%27, iki aşama için \%23 ve üç aşama için \%14 olduğu belirlenmiştir. İki aşama ile üç aşama arasında gözlenen $\% 9$ 'luk oran farkı kendine güven eksikliğinden kaynaklanmaktadır. Alanyazında \%9'luk bu öğrenci grubu bilgi eksikliği kategorisinde değerlendirilmektedir (Arslan, Cigdemoglu \& Moseley, 2012; Hasan, Bagayoko \& Kelley, 1999; Peşman \& Eryılmaz, 2010; Taşlıdere, 2016) Teşhis edilen kavram yanılgılarında her bir aşamada belirgin oranda azalış olduğu gözlenmektedir. Bu durum üç aşamalı SSKÖA'nın öğrencilerin sindirim sistemi konusunda kavram yanılgı oranlarını net bir şekilde belirlemede yeterli olduğunu göstermektedir.

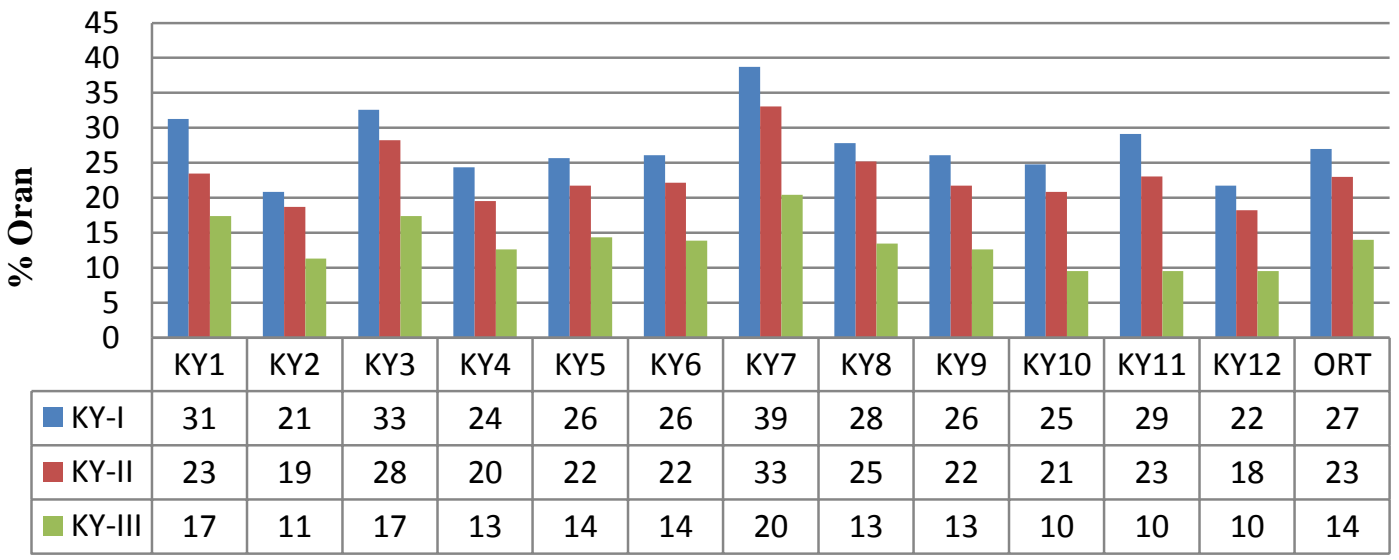

Grafik 2. Belirlenen kavram yanılgılarının aşamalar halinde oranları 
Çalışmadan elde edilen veriler içinde en çok tekrarlanan kavram yanılgısının suyun büyük bölümünün emiliminin nerede gerçekleştiğine yönelik yanılgı olduğu belirlenmiştir. Öğrencilerin toplamda yaklaşık üçte birlik bir bölümü "Suyun büyük bölümü ince bağırsakta emilir (KY3)=\%17" ve "Suyun büyük bölümü böbrekte emilir (KY4)=\%13" şeklinde yanılgılara sahiptir. Örneğin Şekil 1'de belirtilen üçüncü soru ile elde edilen verilere göre öğrencilerin \%63'ü kendinden emin olarak soruya yanıt vermiş olmasına karşın yalnız \%18'i üç aşamanın tamamında doğru yanıta ulaşmıştır. \%30'u ise suyun büyük bölümünün emiliminin nerede gerçekleştiği yönünde kavram yanılgısına sahip olduklarını göstermişlerdir.

Yemek borusunda sindirimin gerçekleştiği yönündeki yanılgı diğer bir dikkat çekici kavram yanılgısıdır. Öğrencilerin \%28'lük bir bölümü "Yemek borusunda fiziksel sindirim gerçekleşir $(\mathrm{KY} 1)=\% 17$ " ve "Yemek borusunda kimyasal ve fiziksel sindirim gerçekleşir (KY2)=\%11" şeklinde yanılgılara sahiptir. Yemek borusunun işlevinin sorulduğu, KY1 ve KY2'nin belirlendiği Şekil 1'deki birinci soru ile ilgili veriler değerlendirildiğinde öğrencilerin \%73'ünün kendinden emin olarak soruya yanıt vermiş olmasına karşın yalnız \%31'inin üç aşamanın tamamında doğru yanıta ulaştığı, \%17'sinin yemek borusunda fiziksel sindirim, \%11'inin ise yemek borusunda hem fiziksel hem de kimyasal sindirim gerçekleştiği yönünde yanılgıya sahip oldukları belirlenmiştir.

Belirlenen diğer bir kavram yanılgısı ise KY5'dir. KY5, öğrencilerin tüm besin öğelerinin sindirime uğraması gerektiği yönündeki görüşlerini ortaya koymaktadır. Öğrencilerin \%14'üne göre "tüm besin öğeleri hücrelere geçecek kadar küçük değildir". Bunun yanında, diğer bir kavram yanılgısı ise öğrencilerin sindirimin başlangıç ve bitişi konusunda görüşlerini yansıtan KY6'dır. Buna göre öğrencilerin \%14'ü "Sindirim ağızda başlayıp kalın bağırsakta sona erer" görüşündedir. KY5 ve KY6'nın belirlendiği, sindirim sistemi ile ilgili genel bir değerlendirmenin yapılmasının beklendiği dördüncü soru şekil 2'de belirtilmiştir. Testin 4. soru maddesinden elde edilen verilere göre öğrencilerin $\% 66$ 'sı kendinden emin olarak soruya yanıt vermiştir. Ancak bunlardan yanlış cevap ve yanlış gerekçe eşliğinde yanıtlar veren öğrenciler her biri \%14'lük orana sahip KY5 ve KY6 şeklinde kavram yanılgısına sahiptirler.

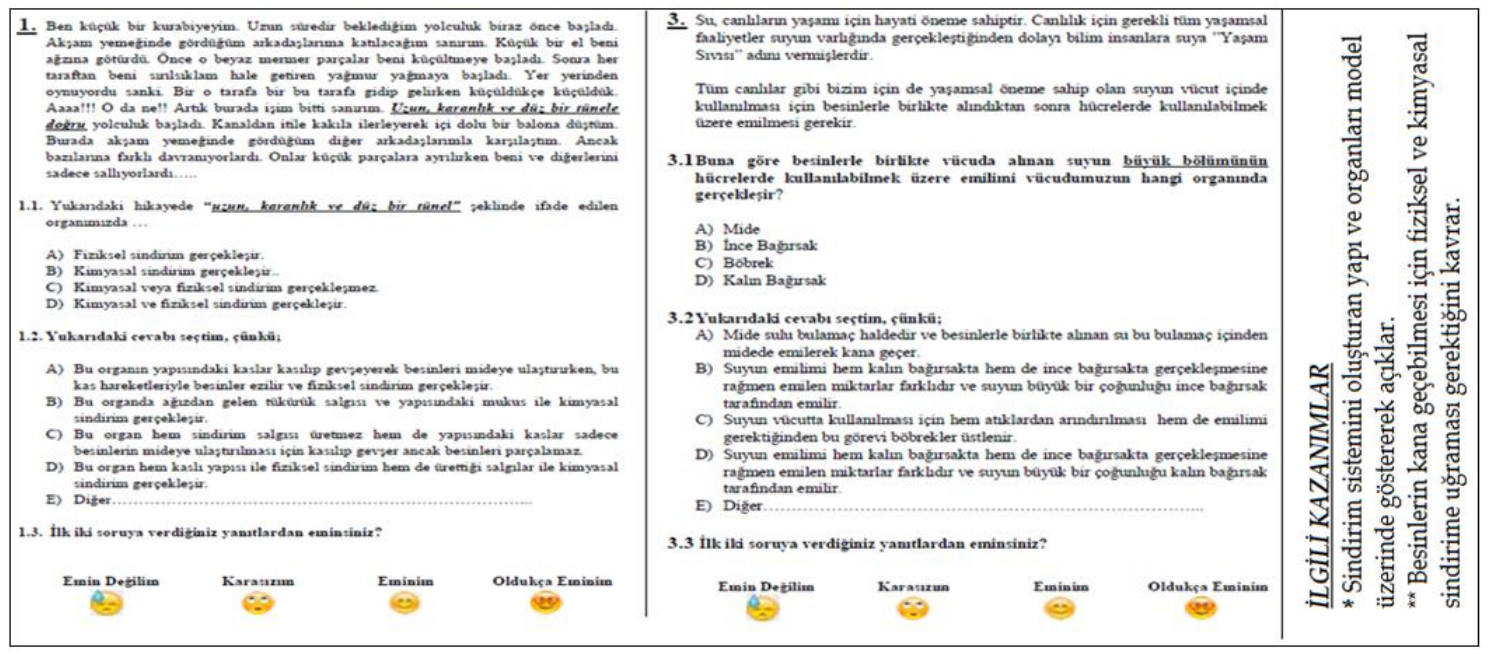

Şekil 1. KY1, KY2, KY3 ve KY4 için örnek soru maddeleri 
Bir diğer kavram yanılgı grubu ise KY11 ve KY12'dir. Buna göre öğrenciler yağların sindirimi konusunda farklı görüşlere sahiptirler. Elde edilen verilere göre öğrencilerin \%10'u yağların sindiriminin pankreasta geçekleştiğine, diğer bir \%10'u ise yağların kimyasal sindiriminin ağız ve midede gerçekleştiğine inanmaktadırlar.

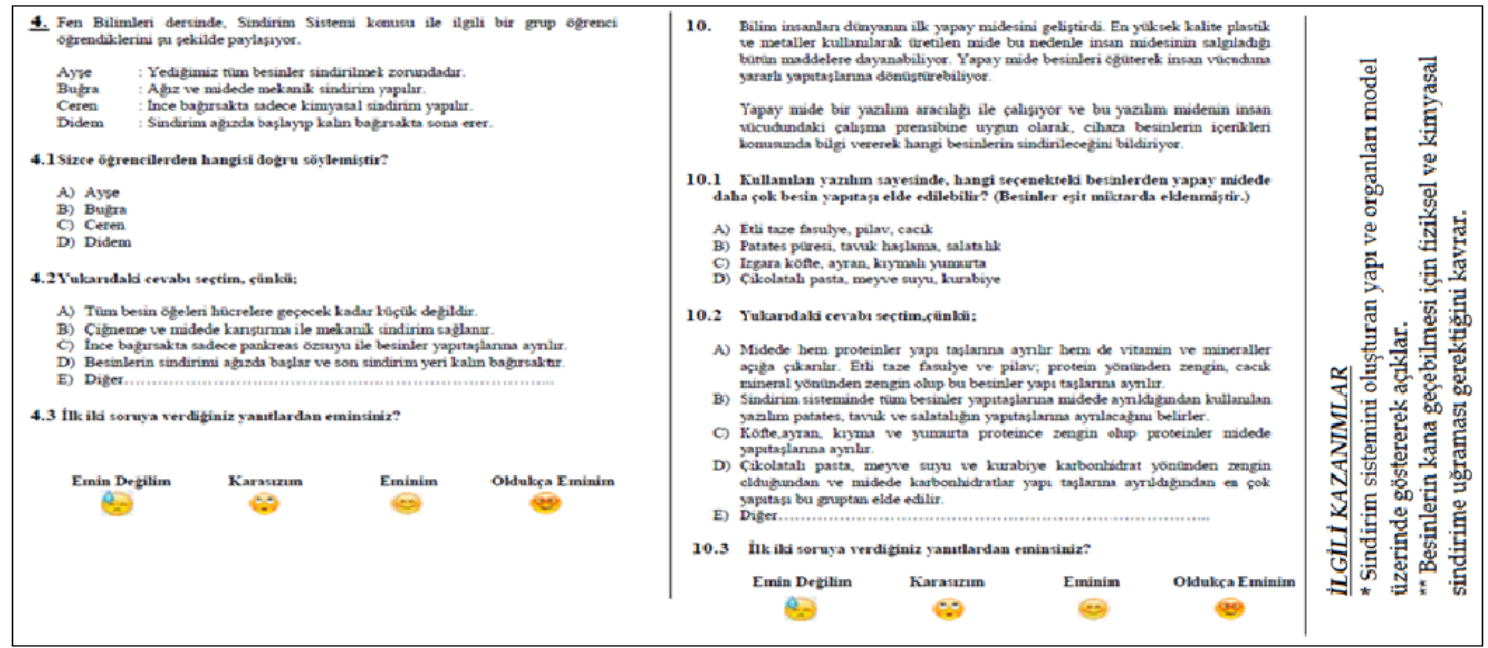

Şekil 2. KY5, KY6 ve KY10 için örnek soru maddeleri

Bunun yanı sıra KY8 öğrencilerin besin yapıtaşlarının değil de besin öğelerinin ince bağırsaktan kana geçeceği yönündeki görüşlerini yansıtmaktadır. Buna göre öğrencilerin \%24'ü besinlerin temel öğeleri olan karbonhidrat protein ve yağların yapıtaşlarının emilerek kana geçtiği yönünde kavramsal anlama düzeyine sahipken \%13'ü ise besinlerin temel öğelerinin yapıtaşlarına ayrılmadan kana geçtiği görüşündedirler. KY8 ile ilişkili olan diğer bir yanılgı ise KY9'dur. KY9'a ilişkin verilere göre öğrencilerin \%13'ü temel besin öğelerinden karbonhidratların yapıtaşlarının yağ asidi ve gliserol olduğuna inanmaktadırlar. Belirlenen son kavram yanılgısı ise KY10'dur. Testin onuncu sorusuna ilişkin öğrencilerden alınan yanıtların analizine göre; öğrencilerin \%47'si kendinden emin olarak cevap vermesine karşın \%19'u bilimsel bilgi eşliğinde soruya doğru yanıt vermiş ancak \%10'u midede tüm besinlerin yapıtaşlarına ayrıldığı görüşünü paylaşmıştır.

SSKÖA ile ilgili veri setinin analiz sonuçlarına göre pozitif yanlış, negatif yanlış, şanslı tahmin ve bilgi eksikliği kategorilerinin (\%) oranları Grafik 3'te belirtilmiştir. Buna göre, testin hazırlanış amacına uygun olarak üç aşamanın birlikte değerlendirilmesi ile yapılan analiz sonuçları pozitif yanlış oranının \% 0-3, negatif yanlış oranının ise \% 0-6 aralığında olduğunu göstermiştir. Alanyazında pozitif yanlış ve negatif yanlış oranlarının \%10'dan az olacak şekilde minimize edilmesi gerektiği belirtilmektedir (Aslan, Çiğdemoğlu \& Moseley, 2012; Halloun \& Hestenes, 1995). Bu doğrultuda elde edilen sonuçlar geliştirilen SSKÖA'nın geçerli, öğrenciler için açık ve problemsiz olduğunu göstermektedir.

Bazı öğrenciler herhangi bir kavram yanılgısına sahip olmamasına rağmen, bilgi eksikliği veya negatif yanlış kategorisinde ilk aşamaya yanlış cevap verebilirler. İki ve üç aşamalı testler negatif yanlışları belirleyebilirken üç aşamalı testler üçüncü aşama sayesinde bilgi eksikliği kategorisini de belirleyebilir (Peşman \& Eryılmaz, 2010). Öğrencilerin kendinden emin olarak yanlış cevap ve gerekçeyi işaretlemeleri halinde kavram yanılgısına düştüğü belirlenebilirken kendinden emin olunmaması halinde bu durum bilgi eksikliği kategorisinde değerlendirmektedir. Buna göre, elde edilen veriler değerlendirildiğinde öğrencilerin ortalama \%25'inin sindirim sistemi konusunda bilgi eksikliğinin bulunduğu gözlenmektedir. Bilgi eksikliği boyutunda en büyük oranın \%39 ile onuncu soruya ait midede proteinlerin sindirimi konusunda ve \%35 ile on birinci soruya ilişkin yağların sindirimi konusunda olduğu 
belirlenmiştir. îki aşamalı testlerde hem cevap hem de gerekçe kısmında doğru şıkkı işaretlemiş bir öğrenci bilimsel bilgi aşamasında değerlendirilmektedir. Ancak, üç aşamalı testlerdeki üçüncü aşama sayesinde tesadüfen doğru cevap ve gerekçeye ulaşmış bir öğrencinin, gerçekten bilimsel bilgiye sahip bir öğrenciden ayrılabilmesi mümkündür. Buna göre, doğru cevap ve gerekçeye ulaşarak üçüncü aşamada kendinden emin olmayan bir öğrencinin bu soruyu tesadüfen doğru cevapladığı sonucuna ulaşılır. Buna göre öğrencilerin ortalama \%11'inin sindirim sistemi konusunda şanslı tahminleri uyarınca yanıt verdikleri görülmektedir.

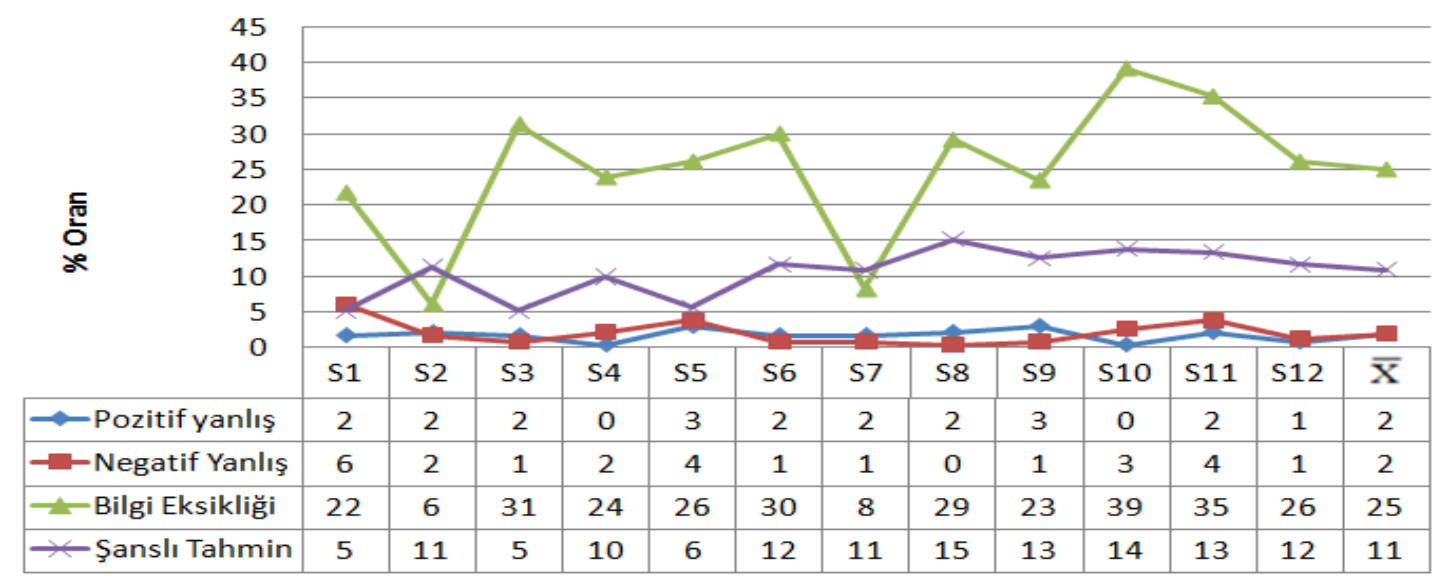

Grafik 3. Pozitif yanlış, negatif yanlış, bilgi eksikliği ve şanslı tahmin oranları (\%)

Öğrencilerin ikinci aşamada kendi gerekçelerini yazabilmelerine olanak sağlayan ( $E$ ) seçeneği çoğu öğrenci tarafından kullanılmamıştır. Ancak bir kısım öğrenci tarafından ilk aşamada ister doğru ister yanlış yanıt vermiş olsun ayrılan (E) şıkkının kullanıldığı belirlenmiştir. Verilen yanıtlardan en belirgin olanları şu şekilde özetlenebilir. Öğrenci 57 (Ö-57), yemek borusunun sindirim sistemindeki görevine ilişkin 1.soruya "Burada sindirim gerçekleşemez bu sadece sindirimin gerçekleşmesine yardımcı olur" şeklindeki kısmen doğru yanıt vermiş olsa da yemek borusunun sindirim sistemi organı değil yardımcı organ olduğunu düşünmektedir. Ö-30, sindirim sistemi sağlığı ile ilgili 2. soruya verdiği "Besinleri çiğnemeden yutar isek bütün halde mideye gider ve besinin tamamı yağ olur" şeklindeki yanıtı ile toplumda yaygın olan bir düşünceye sahip olduğunu göstermiştir. Suyun büyük bölümünün emiliminin gerçekleştiği organın sorulduğu soru için Ö-14 "Böbrekler nefronlar sayesinde suyu süzer", Ö-40 "Su ve içeceklerin sindirimi bağırsaktadır ve villuslar sayesinde gerçekleşir", Ö-82 "Suyu hücrelere ince bağırsakta emilir öyle gider", Ö-132 "Böbrekler kanı süzer kalınbağırsak ise besinleri süzer", Ö208 "Bütün yediğimiz içtiğimiz her şey ince bağırsakta villuslar yardımıyla kana geçer" yanıtlarını vermişlerdir. Sindirim sisteminde en son emilim ve en son sindirimin gerçekleştiği organların sorulduğu testin beşinci sorusu için Ö-34 "Su ve mineraller ince bağırsakta sindirime uğramadan emilir", Ö-57 "Vitamin su ve mineral sindirime uğramadan ince bağırsakta emilir", Ö-82 "Su, mineral vitaminlerin sindirimi ince bağırsakta başlar ve ince bağırsakta biter" ve Ö123 "Vitaminler sindirilmeden ince bağırsakta direk kana geçer" yanıtlarını vermişlerdir. Midede sindirime uğrayan besin öğeleri ile ilgili yapay mide benzetmesinin kullanıldığı onuncu soru için verilen cevaplarda en dikkat çekici ayrıntı öğrencilerin midede proteinlerin sindiriminin gerçekleştiğini bilmesine rağmen besin öğelerini içerikleri yönünden ilişkilendiremedikleridir. Ö-4, Ö-92 ve Ö-163 midede "patates püresi, tavuk haşlama ve salatalık" şeklindeki " $B$ " seçeneğindeki besinlerin protein ağırlıklı olduğunu belirtmişlerdir. Testin sekizinci maddesini oluşturan karbonhidratlar ile proteinlerin ortak yönlerinin sorulduğu soruda Ö-33 "Besinlerin sindirimi hem önce ince bağırsakta sonra kalın bağırsakta emilir" ve Ö194 "Tüm besinlerin sindirimi ağızda başlar" ifadelerini kullanmışlardır. Testin dördüncü sorusunda "Yediğimiz tüm besinler sindirilmek zorundadır" seçeneğini seçen Ö-87 "Eğer 
sindirilmezse hasta oluruz felç iner" ve Ö-215 "Tüm besinler sindirilemezse sindirim sağlığımız olumsuz etkilenir" yanıtlarını vermişlerdir. Elde edilen verilerin değerlendirilmesi neticesinde belirlenen bu gerekçe ifadeleri öğrencilerin kendilerine göre konu ve kavramları yorumladıklarını bir diğer deyişle kavramlar ile ilgili öğretim sırasında değiştirilemeyen yanılgılara sahip olduklarının birer göstergesidir.

\section{TARTIŞMA VE SONUÇ}

Bu çalışma, sindirim sistemine ait üç aşamalı olarak geliştirilen kavramsal ölçme aracı ile ortaokul yedinci sınıf öğrencilerinin sindirim sistemi konusundaki kavram yanılgılarını belirlemek amacıyla gerçekleştirilmiştir. Yapılan analizler neticesinde güvenirlik, madde güçlüğü, madde ayırt ediciliği, point biserial korelasyon katsayısı, pearson momentler çarpım korelasyonu, pozitif ve negatif yanlış oranları ile ilgili elde edilen veriler SSKÖA'nın yedinci sınıf öğrencilerinin sindirim sistemi konusunda kavramsal anlamalarını ve kavram yanılgılarını belirlemeye yönelik güvenilir ve geçerli bir ölçme aracı olduğunu göstermiştir.

Alanyazında üç aşamalı testler kavram yanılgılarının en doğru oranda belirlenebilmesine aracılık eden etkili ölçme araçları olarak görülmektedir. Kendine güven aşaması sadece kavramsal anlama düzeyi ile kavram yanılgılarını belirlemede etkili olmayıp aynı zamanda bilgi eksikliği, şanslı tahmin ile negatif yanlış ve pozitif yanlış verilerini belirlemeyi de sağlamaktadır (Arslan, Çiğdemoğlu \& Moseley, 2012; Hestenes \& Halloun, 1995). SSKÖA ile elde edilen veriler bilimsel bilgi düzeyinde değerlendirildiğinde, doğru cevap ortalaması ilk aşamada \%47 iken iki aşamalı \%44 ve üç aşamalı \%33 olarak belirlenmiştir. Bu sonuçlar öğrencilerin sindirim sistemi konusunda kavramsal anlama düzeylerinin düşük olduğunu göstermektedir. Illk aşamadan itibaren kavramsal anlama oranının azalmasının asıl nedeni bilimsel bilgiye sahip olsun ya da olmasın öğrencilerin ilk aşama için doğru yanıta ulaşma olasılığının yüksek olmasına rağmen, kendinden emin olarak hem doğru yanıtı, hem de ilgili doğru gerekçeye ulaşılabilmesinin ancak bilimsel bilgiye sahip olunması koşuluna bağlı olmasıdır. Öğrencilerin sindirim sistemi ile ilgili kavramsal anlama oranlarının düşük olması, alanyazındaki öğrencilerin sınıfta gerçekleştirilen öğretim faaliyetlerinin sonrasında bile düşük, sınırlı ve beklentilerin altında kavramsal anlama düzeyinde bulunduklarına ilişkin benzer çalışma bulgularını desteklemektedir (Çakıcı, 2005; Öztaş, 2015; Prokop ve Fancovicová, 2006).

Alanyazındaki araştırma bulguları ile bir arada değerlendirildiğinde kavramsal anlama düzeyi yönünden düşük bir orana sahip olmalarının altında; (i) öğrencilerin klasik sorular haricinde SSKÖA'daki gibi hikaye formunda gündelik hayattan test maddelerini anlama ve değerlendirmede eksik kalmaları, (ii) doğru bildikleri kavramların nasıl ve nedenini anlamak yerine ezberlemeyi tercih etmiş olabilecekleri, (iii) sindirim sistemi kavramlarının gözlenemediğinden kısmen soyut kalması, (iv) öğrencilerin özellikleri vücutları ve çevreleri gibi kendilerini ilgilendiren konulara kayıtsız kalmaları, (v) uygulama yapılan okulun sosyo-kültürel yapısı () ile (vi) öğrencilerin demografik karakteristiklerinin bulunduğu söylenebilir (Balım \& Ormancı, 2012; Ercan, Taşdere \& Ercan, 2010; Taşdemir \& Demirbaş, 2010; Yağbasan \& Gülçiçek, 2003).

Elde edilen sonuçlara göre öğrencilerin büyük çoğunluğunun (\%64) sorulara kendinden emin olarak yanıt vermesine karşın, düşük kavramsal anlama düzeyinde (iki aşama için \%44) bulunmaları sindirim sistemi konusunda kavram yanılgılarının bulunduğuna işaret etmektedir. Veri setinin analizi neticesinde sindirim sistemi ile ilgili oniki kavram yanılgısı teşhis edilmiştir. Bu kavram yanılgılarından beşi (KY5-8-9-11-12) alandaki çalışmalara katkı sağlayacağı düşünülen alandan farklı kavram yanılgılarıdır. Teşhis edilen diğer yedi kavram yanılgısı ise alandaki araştırma sonuçları ile benzerdir. 
Kavram yanılgısı yönünden elde edilen veriler içinde en göze çarpanı öğrencilerin en son sindirim ve emilimin nerede gerçekleştiği yönündeki görüşleridir. Sindirim sisteminde en son sindirim yeri ince bağırsaktır. Su, vitamin ve mineraller sindirime uğramadığından emilimi kalın bağırsakta gerçekleştiği için en son emilim ise kalın bağırsakta gerçekleşmektedir. Buna karşın öğrencilerin bir kısmı en son sindirim ve emilimin ince bağırsakta gerçekleştiği (KY7) görüşünde iken bir kısmı "Sindirim ağızda başlayıp, kalın bağırsakta sona erer (KY6)" görüşü ile en son sindirimin kalın bağırsakta gerçekleştiği yönünde kavram yanılgısına sahiptir. Benzer şekilde öğrencilerin kalın bağırsakta sindirimin gerçekleştiği yönündeki kavram yanılgılarının varlığına ilişkin çalışma sonuçlarına rastlamak mümkündür (Çakıcı, 2005; Ös , 2006; Özsevgeç ve diğer., 2012; Öztaş, 2015). Örneğin Ös (2006), 760 öğrenci ile yürüttüğü 710 anketin değerlendirmeye alındığı çalışma sonucunda en çok gözlenen kavram yanılgısının tüm besinlerin sindiriminin mide, yemek borusu ve kalın bağırsakta gerçekleştiği yönünde olduğunu belirlemiştir. Aynı zamanda elde edilen veriler Prokop ve Fancovicová'nın (2006) çalışmalarında belirledikleri kalınbağırsağın işlevinin ince bağırsağın işlevi ile karıştırıldığı şeklindeki yanılgı ile benzerlik göstermektedir. Benzer şekilde suyun emilimi yönünden bir grup öğrenci "Suyun büyük bölümü ince bağırsakta emilir (KY3)" görüşünde iken bir grup öğrenci ise "Suyun büyük bölümü böbrekte emilir (KY4)" görüşündedir. Son yıllarda yapılan birçok çalışma bulgusu da öğrencilerin suyun emiliminin nerede gerçekleştiği yönünde kavram yanılgılarının bulunduğunu göstermektedir (Şahin ve Oktay, 1998; Tekkaya ve diğer., 2000; Uğur, 2010). Bunun yanı sıra sindirim sistemine diğer sistemlere ait organların dahil edildiği çalışma bulgularına da rastlamak mümkündür. Örneğin Pelitoğlu (2006), 6.sınıf öğrencisi 64 öğrenci ile yürüttüğü çalışması neticesinde öğrencilerin sindirim sistemi organları arasına böbreği de dahil ettiklerini belirlemiş̧ir. Bu çalışma neticesinde de benzer bir sonuca ulaşılması öğretim programına göre birbirini takip eden sindirim sistemi ile boşaltım sistemi konularının bir bütün içinde değerlendirilmesi gerekirken birbirine karıştırıldığı gerçeğini göstermiştir. Aynı zamanda elde edilen sonuçlar öğrenciler arasında yaygın benzer kavram yanılgılarının bulunduğuna işaret etmektedir.

Yemek borusu sindirim sisteminin bir parçası olmakla birlikte temel görevi ağızdan alınan besin öğelerinin mideye iletilmesidir. Ancak sonuçlar göstermiştir ki bazı öğrenciler "Yemek borusunda fiziksel sindirim gerçekleşir (KY1)", bazıları ise "Yemek borusunda hem kimyasal hem fiziksel sindirim gerçekleşir (KY2)" şeklinde kavram yanılgılarına sahiptirler. Elde edilen sonuçlar Uğur (2010) ile Özsevgeç ve diğer. (2012) tarafından yürütülen çalışma sonuçları ile benzerlik göstermektedir. Bunun yanında, fiziksel ve kimyasal sindirim kavramlarının öğrencilerin sindirim sistemini anlamlandırmalarındaki temel engel olduğuna işaret eden çalışma bulguları da mevcuttur (Teixeira 2000). Buna göre öğrencilerin yemek borusunda sindirimin gerçekleştiği yönündeki yanılgıları da bu karmaşanın bir sonucu olarak gösterilebilir.

Bu çalışma sonucunda teşhis edilen kavram yanılgılarından biri de KY5'dir. Bu gruptaki öğrenciler tüm besin öğelerinin hücrelere geçecek kadar küçük olmadığını düşünmektedirler. Hâlbuki sindirim besin öğelerinin hücrelere geçecek kadar küçük parçalara ayrılması olarak tanımlanmakta olup; besinler, içerdikleri besin öğelerine göre karbonhidrat, protein, yağ, vitamin, mineral ve su olarak gruplandırılır. Bu besin öğelerinden vitamin ve mineraller ise sindirime uğramadan kana geçebilecek haldedir. Elde edilen bu veri öğrencilerin hangi besin öğelerinin sindiriminin gerçekleşeceği, hangilerinin sindirilmeden direk kana geçebileceği konusunda eksikliklerinin olduğunu ve bu eksiklik çerçevesinde kavram yanılgısına sürüklendiklerini düşündürmektedir. Benzer şekilde öğrencilerin bir kısmı ise sindirim ürünlerinin karbonhidrat, protein ve yağ olduğunu (KY8) düşünme eğilimindedir. Öğrencilerin bu görüşü besin öğelerinin sindirim sonunda yapıtaşlarına ayrılması kavramının yanlış yorumlandığını, öğretim basamaklarında sürekli tekrarlanan karbonhidrat, protein ve yağ 
terimlerinin sindirim ile ilişkilendirildiğini göstermiş̧tir. Buna ek olarak öğrencilerin bir kısmı da "Karbonhidratların yapıtaşları yağ asidi ve gliseroldür (KY9)" şeklinde kavram yanılgısına sahiptir. Bu gruptaki öğrenciler için (i) "sindirim sisteminde besin öğelerinin yapıtaşlarına ayrıldığını biliyor" ve (ii) "karbonhidratların yapı taşlarını bilmiyor" şeklinde iki farklı değerlendirme yapılabilir. Besin öğelerinin yapıtaşlarına ayrıldığını bilmeleri KY8 ile tezattır. Ancak karbonhidratların yapı taşlarının yağların yapı taşları ile ilişkilendirilmesi ise tam bir yanılgı örneğidir. Bunun yanı sıra sonuçlar yağların sindirimi ile ilgili de öğrencilerin farklı kavram yanılgılarına sahip olduklarını göstermektedir. KY11 ve KY12 alandan farklı olarak bu çalışma neticesinde teşhis edilen, yağların sindirim ile ilgili diğer bir kavram yanılgısı grubudur. Buna göre öğrencilerin bir kısmı yağların sindiriminin sadece pankreas özsuyu ile gerçekleştiği, bir kısmı ise yağların kimyasal sindiriminin ağız ve midede gerçekleştiği yönünde yanılgıya sahiptirler. Elde edilen sonuçlar alana katkı sağlayacağı düşünülen, sindirim sistemi ile ilgili alandan farklı kavram yanılgıları olduğunu da göstermektedir.

Belirlenen son kavram yanılgısı ise öğrencilerin tüm besinlerin midede yapıtaşlarına ayrıldığına ilişkin görüşlerini yansıtan KY10'dur. KY10 midenin sindirim sisteminin temel organı olduğu yönünde alanyazındaki benzer çalışma bulguları ile örtüşmektedir. Örneğin, Güngör (2009) ilköğretim yedinci sınıf öğrencileri ile yürüttüğü üç yıllık boylamsal bir araştırma neticesinde öğrencilerin "sindiriminin biricik organı mide" şeklinde bir yaklaşıma sahip olduğunu, bu yaklaşımın hem kültürel hem de medya aracılığıyla yerleştiği ve formal eğitim öncesinde bu temel üzerine kurulu ön bilgiler nedeniyle öğretim sırasında kavram yanılgılarına neden olduğunu belirtmiş̧ir.

Kavram yanılgıları, bilimsel bilgiden bağımsız olarak bireyin kişisel deneyimleri sonucu zihninde oluşan ve/veya toplumsal ve teknolojik etkileşim (aile, okul, arkadaş iletişimi, görselişitsel medya) sonucu zihnine yerleşen alternatif görüşlerdir. Öğretim öncesinde ve/veya öğretim sırasında ortaya çıkan bu kavram yanılgıları öğrencilerin ilgili konu alanında bilimsel bilgiye ulaşmasını engellediği gibi, konu alanına ilişkin ilginin azalmasına, öğrencilerin kendilerini yetersiz hissetmelerine ve dolayısıyla akademik başarılarının olumsuz yönde etki etkilenmesine sebep olmaktadır (Driver \& Easley, 1978; Sarı Ay \& Aydoğdu, 2015; Tekkaya, 2002; Treagust, 1995; 2012; Wessel, 1999). Fen konularının birbiriyle sıkı iliş̧i içinde bulunduğundan hareketle, sindirim sisteminde oluşacak kavram yanılgılarının takip eden ilişkili diğer konularda ve/veya diğer kademelerdeki sindirim sistemi konularında bütünleşik yanılgıya neden olacağı düşünülmektedir.

Çalışma sonucunda elde edilen veriler bir bütün olarak değerlendirildiğinde, alanyazında yer alan benzer kavram yanılgılarına rastlandığı gibi alana katkı sağlayacağı düşünülen alandan farklı kavram yanılgıları da teşhis edilmiştir. Bu kavram yanılgıları sindirim sistemi konusu içinde birbiriyle sürekli ve sıkı bir ilişki içinde bulunan temel kavramları (fiziksel sindirim, kimyasal sindirim, emilim, yapı taşları vs.) içermektedir. Bu nedenle konunun bütünüyle anlaşılmasını engeller niteliktedirler. Bu değerlendirme ışı̆̆ında ilk öneri öğretimde kılavuz vazifesi gören öğretmenler içindir. Öğretmenlerin her kademedeki öğrencilerinin mevcut yerleşmiş kavram yanılgılarını teker teker belirlemesi zor ve zaman alıcı bir süreçtir. Bu bakımdan çalışma sonucunda teşhis edilen kavram yanılgıları ile alanyazında belirlenmiş diğer kavram yanılgıları konusunda öğretmenlerin bilgi sahibi olmaları, bu kavram yanılgılarından öğretim sürecinde engel teşkil edecek olanlarının belirlenerek önleyici tedbirlerin alınması ya da öğretim sürecini buna göre planlamalarının uygun olacağı değerlendirilmektedir. Bunun yanında, bu çalışma ve alanyazındaki diğer çalışmalarla teşhis edilmiş kavram yanılgılarının öğretim programlarının hazırlanması aşamasında değerlendirmeye alınabileceği düşünülmektedir. Ayrıca alanyazında farklı öğretim yöntem ve tekniklerinin öğrencilerin kavramsal anlamalarını arttırdığı ile kavram yanılgılarını azalttığı yönünde birçok çalışma 
bulgusu yer almaktadır (Demir, 2012; Kurtçuoğlu, 2007; Özsevgeç ve diğer., 2012; Rule, 2004; Şahin ve Oktay, 1998; Yel ve Yiğitel, 2005). Bu doğrultuda öğretmenlerin öğretim süreçlerini sınıf ortamı ve düzeyine uygun yöntem ve teknikler ile zenginleştirmeleri halinde kavram yanılgılarının azalmasının muhtemel olduğu düşünülmektedir.

Son olarak, öğrencilerin sindirim sistemi konusunda düşük kavramsal anlama oranı eşliğinde birçok kavram yanılgısına sahip olmaları yönündeki veriler fen bilimlerindeki bilgi, beceri ve okuryazarlık eksikliğine ilişkin genel durumu gösterir niteliktedir. Bu nedenle, sindirim sistemindeki gibi öğrenciler tarafından soyut alglanan kavramların somutlaştırılması açısından modelleme ya da analojilerin kullanılması, öğretmenlere kavram yanılgıları ile ilgili hizmet içi eğitim, seminer ya da kurs verilmesi, çeşitli öğretim yöntem ve tekniklerinin işe koşulması, kavram yanılgılarının eğitim fakültelerindeki öğretmen adaylarına verilecek ders içeriklerine dâhil edilmesi, ders kitaplarının kavram yanılgısına sürüklemeyecek şekilde planlanmasının mevcut kavram yanılgılarının dirençli yapısının ortadan kaldırılmasına ya da yeni kavram yanılgılarının oluşumunu önlemeye yardımcı olacağı değerlendirilmektedir.

\section{KAYNAKLAR}

Alıcı, D., Başol, G., Çakan, M., Kan, A., Karaca, E., Özbek, Ö.Y. \& Yaşar, M. (2011) Eğitimde ölçme ve değerlendirme. Ankara: Pegem Akademi Yayınları.

Arslan, H. O., Çiğdemoğlu, C., \& Moseley, C. (2012). A three-tier diagnostic test to assess preservice teachers' misconceptions about global warming, greenhouse effect, ozone layer depletion, and acid rain. International Journal of Science Education, 34(11), 1667-1686.

Aykutlu, I. \& Şen, A. I. (2012). Üç aşamalı test, kavram haritası ve analoji kullanılarak lise öğrencilerinin elektrik akımı konusundaki kavram yanılgilarının belirlenmesi. Egitim ve Bilim, 37(166), 275.

Ayvacı, H. Ş., Özsevgeç, T., \& Cerrah, L. (2004). Yıldırım kavramının farklı yaş grubundaki öğrencilerde gelişimi. Kastamonu Eğitim Dergisi,12(2), 351-360.

Bahar, M. (2003). Biyoloji eğitiminde kavram yanılgıları ve kavram değişim stratejileri. Kuram ve Uygulamada Eğitim Bilimleri, 3(1), 27-64.

Baki, A. (1999). Cebirle ilgili işlem yanılgılarının değerlendirilmesi. III. Fen Bilimleri Eğitimi Sempozyumu. Trabzon: Karadeniz Teknik Üniversitesi, $23-25$ Eylül 1998, 46-55.

Balım, A. G., Ormancı, Ü. (2012). İlköğretim öğrencilerinin “maddenin tanecikli yapısı” ünitesine yönelik anlama düzeylerinin çizim yoluyla belirlenmesi ve farklı değişkenlere göre analizi. Eğitim ve Öğretim Araştırmaları Dergisi 1(4), 255-265.

Büyüköztürk, Ş. (2007). Sosyal Bilimler İçin Veri Analizi El Kitabı (8. Baskı). Ankara: PegemA Yayıncilık.

Büyüköztürk, S., Kiliç Çakmak, E., Akgün, O. E., Karadeniz, S. \& Demirel, F. (2009). Bilimsel araştirma yöntemleri. Ankara: Pegem Akademi.

Caleon, I., \& Subramaniam, R. (2010). Development and application of a three-tier diagnostic test to assess secondary students' understanding of waves. International Journal of Science Education, 32(7), 939-961.

Carvalho, G. S., Silva, R., Lima, N., Coquet, E. \& Clément, P. (2004). Portuguese primary school children's conceptions about digestion: identification of learning obstacles. International Journal of Science Education, 26(9), 1111-1130. 
Çakıcı, Y. (2005). Exploring Turkısh upper primary level pupils' understanding of digestion. International Journal of Science Education, 27 (1), 79-100.

Çakır, S. Ö., \& Yürük, N. (1999). Oksijenli ve oksijensiz solunum konusunda kavram yanılgıları teşhis testinin geliştirilmesi ve uygulanması. III. Fen Bilimleri Eğitimi Sempozyumu, Trabzon: Karadeniz Teknik Üniversitesi, 23-25 Eylül 1998, 193-198.

Çardak, O. (2015). Student science teachers' ideas of the digestive system. Journal of Education and Training Studies, 3(5), 127-133.

Çataloglu, E. (2002). Development and validation of an achievement test in introductory quantum mechanics: The quantum mechanics visualization instrument (QMVI). Yayımlanmamış doktora tezi. Pennsylvania State University.

Çetin-Dindar, A., \& Geban, O. (2011). Development of a three-tier test to assess high school students' understanding of acids and bases. Procedia-Social and Behavioral Sciences, 15(2011), 600-604.

Çetinkaya, M., \& Taş, E. (2016). "Vücudumuzda sistemler" ünitesine yönelik üç aşamalı kavram tanı testi geliştirilmesi. Sosyal Bilimler Arastirmalari Dergisi, (15), 317-330.

Demir, R. (2008). Zihinsel engelli öğrencilere fen bilgisi dersinde sindirim konusunu basamaklandırılmış ögretim yöntemiyle sunulmasının etkililiği. Yayımlanmamış doktora tezi. Konya: Selçuk Üniversitesi.

Demir, M. (2012). 7.sınıf vücudumuzdaki sistemler ünitesinin oyun tabanlı öğrenme yaklaşımı ile işlenmesinin öğrencilerin akademik başarılarına ve fen teknoloji dersine karşı tutumlarına etkisi. 10. Ulusal Fen Bilimleri ve Matematik Eğitim Kongresi. Niğde: Niğde Üniversitesi, 27-30 Haziran 2012.

Driver, R., \& Easley, J. (1978). Pupils and paradigms: A review of literature related to concept development in adolescent science students. Studies in Science Education, 5, 61-84.

Duit, R., \& Treagust, D. F. (2003). Conceptual change: A powerful framework for improving science teaching and learning. International journal of science education, 25(6), 671-688.

Ekiz, M. (2015). Model ve etkinliklerle desteklenen öğretim sürecinin sindirim sistemi konusundaki kavram yanılgıları ve bilgi eksiklikleri üzerindeki etkisi. Yayımlanmamış yüksek lisans tezi. Trabzon: Karadeniz Teknik Üniversitesi, Eğitim Bilimleri Enstitüsü.

Ercan, F., Taşdere, A., \& Ercan, N. (2010). Kelime ilişkilendirme testi aracılı̆̆ıyla bilişsel yapının ve kavramsal değişimin gözlenmesi. Türk Fen Eğitimi Dergisi, 7(2), 136-154.

Garcia-Barros, S., Martínez-Losada, C., \& Garrido, M. (2011). What do children aged four to seven know about the digestive system and the respiratory system of the human being and of other animals?. International Journal of Science Education, 33(15), 2095-2122.

Gilbert, J. K. (1977). The study of student misunderstandings in the physical sciences. Research in Science Education, 7(1), 165-171.

Gilbert, J., Osborne, R., \& Fensham, P. (1982). Children's science and its consequences for teaching. Science Education, 66, 623-633.

Güçlüer, E., \& Kesercioğlu, T. (2011). A study on 7th grade students' misconceptions on the unit of "systems of our body". II. World Conference on New Trends in Science Education (WCNTSE). Kuşadası, 19-23 Eylül 2011. 
Güngör, B. (2009). Insanda sindirim sistemi konusunda ilköğretim 7. sınıf öğrencilerinin kavram yanılgılarının kökenlerinin belirlenmesine yönelik boylamsal bir çalışma. Yayımlanmamış doktora tezi. Balıkesir: Balıkesir Üniversitesi Fen Bilimleri Enstitüsü.

Güngör, B., \& Özgür, S. (2009). Illköğretim beşinci sınıf öğrencilerinin sindirim sistemi konusundaki didaktik kökenli kavram yanılgılarının nedenleri. Necatibey Eğitim Fakültesi Elektronik Fen ve Matematik Eğitimi Dergisi, 3(2), 149-177.

Halloun, I. A., \& Hestenes, D. (1985). The initial knowledge state of college physics students. American journal of Physics, 53(11), 1043-1055.

Hammer, D. (1996). More than misconception: multiple perspectives on student knowledge and reasoning, and an appropriate role for education research. American Journal of Physics, 64(10), 1316-1325.

Hasan, S., Bagayoko, D., \& Kelley, E. L. (1999). Misconceptions and the certainty of response index (CRI). Physics education, 34(5), 294-299.

Hashweh, M. (1988). Descriptive studies of students' conceptions in science. Journal of Research in Science Teaching, 25(2), 121-134.

Helm, H. (1980). Misconceptions in physics amongst South African students. Physics Education, 15(2), 92-105.

Holland, S., Griffiths, R., \& Woodman, M. (1997, March). Avoiding object misconceptions. In ACM SIGCSE Bulletin (Vol. 29, No. 1, pp. 131-134). 04 Aralık 2016 tarihinde https://pdfs.semanticscholar.org/245f/e88ca316ec28d3161a6c4a5cc806e3703a59.pdf adresinden erişilmiştir.

Jang, N. H. (2003). Developing and validating a chemical bonding instrument for korean high school students. Yayımlanmamış tez. Missouri: The Faculty Graduate School University.

Klopfer, L. E., Champagne, A. B., \& Gunstone, R. F. (1983). Naive knowledge and science learning. Research in Science \& Technological Education, 1(2), 173-183.

Karasar, N. (2009). Bilimsel araştırma yöntemi. Ankara: Nobel Yayın.

Kurtçuoğlu, S. (2007). Lise II. sınıf biyoloji dersi sindirim sistemi konusunda uygulanan çoklu zeka kuramının öğrencilerin başarılarına etkisi. Yayımlanmamış yüksek lisans tezi. Ankara: Gazi Üniversitesi.

McCloskey, M., Caramazza, A., \& Green, B. (1980). Curvilinear motion in the absence of external forces: Naive beliefs about the motion of objects. Science, 210(4474), 11391141.

Milli Eğitim Bakanlığı (MEB) (2006). Illköğretim fen ve teknoloji dersi (6, 7 ve 8. sınıflar) öğretim programı. Ankara: MEB Talim ve Terbiye Kurulu Başkanlığı.

Mintzes, J. J. (1984). Naive theories in biology. Children's concepts of human body. School Science and Mathematics, 84, 548-554.

Novak, J. D. ve Gowin, D.B. (1984). Learning how to learn. New York: Cambridge University Press.

Nunez, F. ve Banet, E. (1997). Students' conceptual patterns of human nutrition. International Journal of Science Teaching, 19, 509-526.

Osborne, R.J. \& Gilbert, J.A. (1980), A Method for Investigation of Concept Understanding in Science. Europen Journal of Science Education, 20(9), 825-838. 
Özgür, S., \& Pelitoglu, F. C. (2008). The investigation of 6th grade student misconceptions originated from didactic about the "digestive system" subject. Educational Sciences: Theory \& Practice, 8(1), 149-159.

Öztaş, H. (2015). First -year universıty students' misconceptions about digestive tract and its functions. TIIKM Journal of Education, 1(1), 119-123.

Ös, S. (2006). Illkögretim 6, 7 ve 8. sınıf fen bilgisi müfredatındaki biyoloji kavramlarının anlaşılma düzeyinin tespit edilmesi ve anlaşılmama nedenlerinin incelenmesi. Yayımlanmamış yüksek lisans tezi. Van: Yüzüncü Yıl Üniversitesi Eğitim Fakültesi.

Özbilen, A.,G. (2015). Kavramçarkı diyagramının öğrencilerin kavramsal gelişimlerine, motivasyonlarınave biyolojiye yönelik tutumlarına etkisinin belirlenmesi. Yayımlanmamış yüksek lisans tezi. (Adana: Çukurova Üniversitesi Sosyal Bilimler Enstitüsü.

Özsevgeç, L. C., Artun, H., \& Ünal, M. (2012). The effects of Swedish Knife Model on students' understanding of the digestive system. In Asia-Pacific Forum on Science Learning and Teaching (Vol. 13, No. 2).

Pelitoğlu, F., (2006). İlköğretim 6. sınıf "sindirim sistemi" konusunun transpozisyon didaktik teorisine göre incelenmesi. Yayımlanmamış yüksek lisans tezi. Balıkesir: Balıkesir Üniversitesi Fen Bilimleri Enstitüsü.

Peşman, H., \& Eryılmaz, A. (2010). Development of a three-tier test to assess misconceptions about simple electric circuits. The Journal of Educational Research, 103(3), 208-222.

Pfundt, H., \& Duit, R. (1991). Bibliography: Students' alternative frameworks and science education. Kile, Germany: University of Kiel Institute for Science Education.

Prokop, P., \& Fancovicová, J. (2006). Students' ideas about the human body: Do they really draw what they know. Journal of Baltic Science Education, 2(10), 86-95.

Rule, C. A. (2004). Using form and function analogy object boxes to teach human body systems. School Science and Mathematics, 104 (4), 155-169.

Sarı Ay, Ö., \& Aydoğdu, C. (2015). Maddenin halleri ve ısı konusunda kavram yanılgılarının giderilmesinde kavramsal değişim metinlerinin etkisi. Hacettepe Üniversitesi Eğitim Fakültesi Dergisi, 30(2), 99-111.

Schmidt, H. J. (1997). Students' misconceptions-looking for a pattern. Science education, 81(2), 123-135.

Sutton, C. R. (1980). The learner's prior knowledge: A critical review of techniques for probing its organisation. European Journal of Science Education, 2, 107-120.

Şahin, F. ve Oktay, A. (1998). Illkokul öğrencilerinde el yapması modeller ve dramatizasyonla biyolojik kavramlar ve aralarındaki ilişkilerin öğretilmesi. M.Ü. Atatürk Eğitim Fakültesi Eğitim Bilimleri Dergisi, 10, 265-277.

Tan, K. C. D., Goh, N. K., Chia, L. S., \& Treagust, D. F. (2002). Development and application of a two-tier multiple choice diagnostic instrument to assess high school students' understanding of inorganic chemistry qualitative analysis. Journal of research in Science Teaching, 39(4), 283-301.

Taşdemir, A., \& Demirbaş, M. (2010). Illköğretim öğrencilerinin fen ve teknoloji dersinde gördükleri konulardaki kavramları günlük yaşamla ilişkilendirebilme düzeyleri. Uluslararası Insan Bilimleri Dergisi, 7(1), 124-148. 
Taşlıdere, E. (2016). Development and use of a three-tier diagnostic test to assess high school students' misconceptions about the photoelectric effect. Research in Science \& Technological Education, 34(2), 164-186.

Teixeira, M. F. (2000). What happens to the food we eat? Children's conceptions of the structure and function of the digestive system. International Journal of Science Education, 22(5), 507-520.

Tekkaya, C., Çapa, Y. ve Yılmaz Ö. (2000). Biyoloji öğretmen adaylarının biyoloji konularındaki kavram yanılgıları. Hacettepe Üniversitesi Eğitim Fakültesi Dergisi, 18, 140-147.

Thompson, F. \& Logue, S. (2006). An exploration of common student misconceptions in science. International Education Journal, 7(4),553-559.

Toyoma, N. (2000). What are food and air like Inside our bodies? Children's thinking about digestion and respiration. International Journal of Behavioral Development,24(2), 220230.

Treagust, D. F. (1985). Diagnostic tests to evaluate student misconceptions in science. Science Education Association of Western Australia: Western Australian College of Advanced Education, Perth, October 1984, 17.

Treagust, D. F. (1995). Diagnostic assessment of students' science knowledge. In Learning science in the schools. Glynn, S. M. \& Duit, R. (eds). New Jersey: Lawrence Erlbaum Associates Publishers.

Treagust, D. F. (2012). Diagnostic assessment in science as a means to improving teaching, learning and retention. In Proceedings of The Australian Conference on Science and Mathematics Education (formerly UniServe Science Conference).

Treagust, D. F., \& Chandrasegaran, A. L. (2007). The Taiwan national science concept learning study in an international perspective. International Journal of Science Education, 29(4), 391-403.

Trowbridge, J. E., \& Mintzes, J. J. (1985). Students' alternative conceptions in animal classification. School Science and Mathematics, 85(4), 304-316.

Tuncay, T., Akçam, H. K., \& Dökme, í. (2011). Üç aşamalı sorularla sınıf öğretmeni adaylarının bazı temel fen kavramları hakkında sahip oldukları kavram yanılgıları. Gazi Üniversitesi Gazi Eğitim Fakültesi Dergisi, 31(3), 817-842.

Türk eczacılar birliği (TEB) (2006). TEB haberler eylül-ekim 2006. Ankara: Türk eczacılar birliği. http://www.e-kutuphane.teb.org.tr/pdf/tebhaberler/eylul_ekim06/16.pdf adresinden temin edilmiştir.

Uğur, U.K. (2010). Lise öğrencilerinin sindirim sistemi ile ilgili kavram yanılgılarının iki aşamalı testler ile tespit edilmesi. Yayımlanmamış yüksek lisans tezi. Konya: Selçuk Üniversitesi, Eğitim Bilimleri Enstitüsü.

Viennot, L. (1979). Spontaneous reasoning in elementary dynamics. European Journal of Science Education, 1(2), 205-221.

Wessel, W. (1999). Knowledge construction in high school physics: A study student teacher interaction. Saskatchewan School Trustees Association Research Centre Report.

Wuttiprom, S., Sharma, M. D., Johnston, I. D., Chitaree, R., \& Soankwan, C. (2009). Development and use of a conceptual survey in introductory quantum physics. International Journal of Science Education, 31(5), 631-654. 
Yağbasan, R., \& Gülçiçek, A. G. Ç. (2003). Fen öğretiminde kavram yanılgılarının karakteristiklerinin tanımlanması. Pamukkale Üniversitesi Eğitim Fakültesi Dergisi, 13(13), 102-120.

Yel, M. ve Yiğitel, S. (2005). Lise II. sınıf biyoloji dersi sindirim sistemi konusunda uygulanan çoklu zeka kuramının öğrencilerin başarısına etkisi. 04 Aralık 2016 tarihinde http://kongre.nigde.edu.tr/xufbmek/dosyalar/tam_metin/pdf/2302-29_05_201208_30_30.pdf adresinden edinilmiştir.

Yürük, N., \& Çakır, Ö. S. (2000). Lise öğrencilerinde oksijenli ve oksijensiz solunum konusunda görülen kavram yanılgılarının saptanması. Hacettepe Üniversitesi Eğitim Fakültesi Dergisi, 18, 185-191. 


\section{SUMMARY}

The topics in science classes have many abstract topics, and students have misconceptions some of them coming from the period before they start education and some of them occur during their educations. The observation that misconceptions prevent meaningful and permanent learning because of the nature which is difficult to change prompted researchers to determine such misconceptions (Arslan, Cigdemoglu, \& Moseley, 2012; Peşman \& Eryılmaz, 2010; Taşlıdere, 2016; Toyoma, 2000). The topics in science classes proceed in a spiral way and complement each other. One of these spiral topics is the digestive system. "The digestive system, nutrients and digestion" are the concepts that have preserved their importance since early times, and many individuals have pre-knowledge on these concepts before they start formal education (Güngör, 2009). Since the findings of recent studies show that the foreknowledge of the students cause that students frequently have misconceptions during their formal education, it is necessary to determine the foreknowledge given to students and their misconceptions. The purpose of the study, which was conducted in this context, is to determine the misconceptions of seventh grade students on digestive system by using a 3-tier test.

The review method, which is among the most-frequently used descriptive study methods, was applied in the study. The study was conducted on 230 students, 111 male (48\%), and 119 female (52\%), studying at the seventh grade at a state school in Izmir, Buca County in 2016-2017 Academic Year. The Digestive System Conceptual Measuring Tool (DSCMT), which consisted of three tier and 12 questions, was used as the data collection tool in the study. The first tier is the question part in which there are distractors that include possible misconceptions and the true answer. In the second tier, there are the justifications on the answers given in the first part. In the third tier, there is the "SelfConfidence" part in which the answers of the students given in the first and second stage aremeasured with statements like "I am not sure; I am indecisive; I am sure; I am extremely sure". The Cronbach Alpha Reliability Coefficients for the first tier, two tier and three tier of the tool were calculated as 0,71 , $0,75,0,78$, respectively. In addition, the lower and upper groups of the DSCMT were defined with $27 \%$ rate, and the item difficulty of the first tier was determined as 0,31-0,78; the distinctiveness was determined as 0,37-0,77; the item difficulty of the two tier was determined as $0,28-0,76$, the distinctiveness was determined as $0,44-0,77$; the item difficulty of the three tier was determined as 0,21- 0,60; the distinctiveness was determined as 0,35-0,77. On the other hand, special care was given to cover some assumptions that have to exist in a measuring tool. The relation between two tier point and the self-confidence point in the third tier of the measuring scale was investigated with Pearson Product-Moment Correlation Coefficient for structural validity; and it was determined that there was a positive and significant relation $(r=0,31, p<0,01)$. In addition, the Point Biserial Correlation Coefficient was calculated to determine whether the test items differentiated between the students who received high points and those who received low points; and it was determined that the average correlation coefficient of the test was 0.54 . It was also determined that all the items in the measuring scale had values higher than 0.20 and were acceptable. In addition, it was determined with the calculations on False Negative and False Positive, which should be minimized to be less than $10 \%$ for the content validity that the False Positive rate was 0-3\%; and False Negative rate was $0-6 \%$. The answers of the students were analyzed in the following categories; Scientific Knowledge, Misconceptions, False Positive, False Negative, Lucky Guess, and Lack of Knowledge.

The data obtained in DSCMT showed that the conceptual understanding levels of the students on digestive system was $47 \%$ at the first tier, $44 \%$ at the two tier, and $33 \%$ at the three tier. According to the results, although the majority of the students (64\%) had self-confidence when answering the questions, they were at lower conceptual understanding level (for two tier 44\%), which showed that the students have misconceptions. In the analysis of the dataset, a total of twelve misconceptions 5 of which were different from the field (KY 5-8-9-11-12) and the rest in previous studies on digestive system. The misconceptions adopted by the students were as follows; "The latest digestion and absorption happens in the small intestines" (KY7) 20\%; "The majority of water is absorbed in the small intestines" (KY3) 17\%; "Physical digestion occurs in the esophagus" (KY1)17\%; "Not all nutrient elements are as small as to penetrate through cells" (KY5) 14\%; "Digestion starts in the mouth and ends in the large intestines" (KY6) 14\%; "The majority of water is absorbed in the kidneys" (KY4) 13\%; "Digestion products are carbohydrates, proteins and fat" (KY8) 13\%; "The building blocks of carbohydrates are fat 
acids and glycerol" (KY9) 13\%; "Chemical and physical digestion occurs in esophagus" (KY2) 11\%; "All nutrients are decomposed to their building blocks in the stomach" (KY10) 10\%; "The digestion of the fats occurs only with the pancreatic juice" (KY11) 10\%; and "The chemical digestion of fats occur in the mouth and the stomach" (KY12) 10\%.

When the data obtained in the study are assessed as a whole, it is observed that there are misconceptions mentioned in the literature and there are also some misconceptions which are different fom the field. These misconceptions include some basic concepts (physical digestion, chemical digestion, absorption, building blocks, etc.) that are interrelated closely with each other about the digestive system. For this reason, they prevent the complete understanding of the topic. In this context, supporting the classes with experiments and visual aids, and concretization of abstract concepts may help to eliminate the resistant structure of misconceptions or prevent the formation of new ones. 